NBER WORKING PAPER SERIES

\title{
WHAT DRIVES DIFFERENCES IN MANAGEMENT?
}

\author{
Nicholas Bloom \\ Erik Brynjolfsson \\ Lucia Foster \\ Ron S. Jarmin \\ Megha Patnaik \\ Itay Saporta-Eksten \\ John Van Reenen \\ Working Paper 23300 \\ http://www.nber.org/papers/w23300
NATIONAL BUREAU OF ECONOMIC RESEARCH
1050 Massachusetts Avenue
Cambridge, MA 02138
March 2017

Any opinions and conclusions expressed herein are those of the authors and do not necessarily represent the views of the U.S. Census Bureau or the National Bureau of Economic Research. All results have been reviewed to ensure that no confidential information was disclosed. Financial support was provided in part by the National Science Foundation, Kauffman Foundation and the Sloan Foundation and administered by the National Bureau of Economic Research. In addition, Bloom thanks the Toulouse Network for Information Technology, Brynjolfsson thanks the MIT Initiative on the Digital Economy and Van Reenen thanks the European Research Council and Economic and Social Research Council for financial support. Saporta-Eksten thanks the Pinhas Sapir Center for financial support. We thank Hyunseob Kim for sharing data on large plant openings. We are indebted to numerous Census Bureau staff for their help in developing, conducting and analyzing the survey; we especially thank Julius Smith, Cathy Buffington, Scott Ohlmacher and William Wisniewski. This paper is an updated version of a working paper previously titled "Management in America" and we thank our formal discussant Andrea Pratt as well as numerous participants at seminars for many helpful comments. .

NBER working papers are circulated for discussion and comment purposes. They have not been peer-reviewed or been subject to the review by the NBER Board of Directors that accompanies official NBER publications.

(C) 2017 by Nicholas Bloom, Erik Brynjolfsson, Lucia Foster, Ron S. Jarmin, Megha Patnaik, Itay Saporta-Eksten, and John Van Reenen. All rights reserved. Short sections of text, not to exceed two paragraphs, may be quoted without explicit permission provided that full credit, including (C) notice, is given to the source. 
What Drives Differences in Management?

Nicholas Bloom, Erik Brynjolfsson, Lucia Foster, Ron S. Jarmin, Megha Patnaik, Itay Saporta-Eksten, and John Van Reenen

NBER Working Paper No. 23300

March 2017

JEL No. L2,M2

\section{ABSTRACT}

Partnering with the Census we implement a new survey of "structured" management practices in 32,000 US manufacturing plants. We find an enormous dispersion of management practices across plants, with $40 \%$ of this variation across plants within the same firm. This management variation accounts for about a fifth of the spread of productivity, a similar fraction as that accounted for by $R \& D$, and twice as much as explained by IT. We find evidence for four "drivers" of management: competition, business environment, learning spillovers and human capital. Collectively, these drivers account for about a third of the dispersion of structured management practices.

Nicholas Bloom

Stanford University

Department of Economics

579 Serra Mall

Stanford, CA 94305-6072

and NBER

nbloom@stanford.edu

Erik Brynjolfsson

MIT Sloan School of Management

100 Main Street, E62-414

Cambridge, MA 02142

and NBER

erikb@mit.edu

Lucia Foster

Center for Economic Studies

Census Bureau

Room 2K124

Washington, DC 20233-6300

lucia.s.foster@census.gov

Ron S. Jarmin

U.S. Census Bureau

4600 Silver Hill Road

Washington, DC 20233

ron.s.jarmin@census.gov
Megha Patnaik

Department of Economics

Stanford University

579 Serra Mall,

Stanford, CA 94305 - 6072

mpatnaik@stanford.edu

Itay Saporta-Eksten

The Eitan Berglas School of Economics

Tel Aviv University

P.O.B. 39040

Ramat Aviv, Tel Aviv, 6997801

itaysap@post.tau.ac.il

John Van Reenen

MIT Department of Economics

The Morris and Sophie Chang Building

E62-518

50 Memorial Drive

Cambridge, MA 02142

and NBER

vanreene@mit.edu 


\section{Introduction}

The interest of economists in management goes at least as far back as On the Sources of Business Profits by Francis Walker (1887), the founder of the American Economic Association and the Superintendent of the 1870 and 1880 Censuses.1 This interest has persisted until today. For example, Syverson's (2011) survey of productivity devotes a section to management as a potential driver, noting that "no driver of productivity has seen a higher ratio of speculation to research." Work evaluating differences in management is often limited to relatively small samples of plants (e.g., Ichniowski, Shaw and Prenushi, 1997; Bresnahan, Brynjolfsson and Hitt, 2002), developing countries (e.g., Bloom, Eifert, Mahajan, McKenzie and Roberts, 2013, and Bruhn, Karlan and Schoar, 2016) or particular historical episodes (e.g., Giorcelli, 2016). In addition, although previous work on larger samples such as Bloom, Sadun and Van Reenen (2016) has measured differences in management across firms and countries, there is no large-scale work on the variations in management between the plants2 within a firm.

There are compelling theoretical reasons to expect that management matters for performance. Gibbons and Henderson (2013) argue that management practices are a key reason for persistent performance differences across firms due to relational contracts. Brynjolfsson and Milgrom (2013) emphasize the role of complementarities among management and organizational practices. Halac and Prat (2016) show that "engagement traps" can lead to heterogeneity in the adoption of practices even when firms are ex ante identical. This paper provides empirical evidence for the role that management practices play in firm and plant performance by examining the first large sample of plants with this information.

We partnered with the Economic Program Directorate of the U.S. Census Bureau to develop and conduct the Management and Organizational Practices Survey (MOPS).3 This is the first-ever mandatory government management survey, covering more than 30,000 plants across more than 10,000 firms. 4 The size and high response rate of the dataset, its coverage of units within

1 Walker was also the second president of MIT and the vice president of the National Academy of Sciences. Arguably Adam Smith's discussion of the famous Pin Factory and the division of labor was an even earlier antecedent.

2 Because we are focusing on manufacturing, we use the words "plants" and "establishments" interchangeably.

3 This survey was only possible with the generous provision of over \$1 million of research support from our primary donors - the National Science Foundation, the Kauffman Foundation and the Sloan Foundation.

4 See the descriptions of MOPS in Bloom, Brynjolfsson, Foster, Jarmin, Saporta-Eksten, and Van Reenen (2013) and Buffington, Foster, Jarmin and Ohlmacher (2016). 
a firm, its links to other Census data, as well as its comprehensive coverage of industries and geographies makes it unique, and it enables us to address some of the major gaps in the recent management literature.

We start by examining the variation in management practices across plants, showing three key results. First, there is enormous inter-plant variation in management practices. Although 18\% of establishments adopt three-quarters or more of a package of basic structured management practices for performance monitoring, targets and incentives, $27 \%$ of establishments adopt less than half of such practices. Second, about $40 \%$ of the variation in management practices is across plants within the same firm. That is, in multi-plant firms, there is considerable variation in practices across units. 5 The analogy for universities would be that variations in management practices across departments within universities are almost equally large as the variations across universities. Third, these variations in management practices are increasing in firm size. That is, larger firms have substantially more variation in management practices. This appears to be largely explained by the greater spread of larger firms across different geographies and industries.

We then turn to examining whether our management measures are linked to performance. We find that plants using more structured management practices have greater productivity, profitability, innovation (as proxied by R\&D and patent intensity) and growth. This relationship is robust to a wide range of controls including industry, education, plant and firm age, and possible survey noise. The relationship between management and performance also holds over time within plants (plants that adopted more of these practices between 2005 and 2010 saw improvements in their performance between 2005 and 2010) and across establishments within firms at a point of time (establishments within the same firm with more structured management practices achieve better performance outcomes). These management practices also have a highly significant predictive power for future growth and firm survival up to three years ahead (the current limit of our data after the MOPS survey).

5 A literature beginning with Schmalensee (1985) has examined how the variance in profitability of business across business divisions decomposes into effects due to company headquarters, industry and other factors. Several papers have examined productivity differences across sites within a single firm. For example, Chew, Bresnahan and Clark (1990) looked at 40 operating units in a commercial food division of a large US corporation (the top ranked unit had revenue based Total Factor Productivity twice as high as the bottom ranked). Argote et al. (1990) showed large differences across 16 Liberty shipyards in World War II. Freeman and Shaw (2009) contains several studies looking at performance differences across the plants of single multinational corporations. 
The magnitude of this management-productivity relationship is large. Increasing structured management from the $10^{\text {th }}$ to $90^{\text {th }}$ percentile can account for about $18 \%$ of the comparable $90-10$ spread in firm total factor productivity (TFP).6 Using the same dataset, we also examine the association of productivity with other common "drivers" and find that the 90-10 spread in R\&D accounts for about $17 \%$ of the spread in firm TFP, employee skills about $11 \%$, and IT expenditure per employee about $8 \%$. Of course, all these magnitudes are dependent on a number of other factors, such as the degree of measurement error in each variable, but they do highlight that variation in management practices is likely a key factor accounting for variation in TFP. These factors are also interrelated - when we examine them jointly, we find they account for about 33\% of the total variation in 90-10 productivity. Given estimates that about $50 \%$ of the variation in productivity is measurement error (Collard-Wexler, 2013 and Bloom, Floetotto, Jaimovich, Saporta and Terry, 2016), this suggests that these factors - management, innovation, IT and skills - together account for about two-thirds of the real spread in firm productivity.

We next examine some "drivers" of management practices. We focus our analysis on four potential candidates: product market competition, business environment, learning spillovers from large manufacturing plant entry (primarily belonging to multinational corporations), and education.

The selection of these four factors follows from the existing management and productivity literature which is motivated by a number of different theoretical perspectives (e.g. Syverson, 2011 or Gibbons and Roberts, 2013). One perspective that binds our drivers together follows Walker (1887) and considers some forms of structured management practices to be akin to a productivityenhancing technology. This naturally raises the question of why all plants do not immediately adopt these practices. One factor is differential ability, which motivates our examination of human capital. Another factor is information - not all firms are aware of the practices or believe that they would be beneficial. This motivates our examination of diffusion-based learning and informational spillovers from Million Dollar Plants. Finally, the degree to which the higher ability/better informed establishments drive out their less productive counterparts will depend on the environment. The selection of such plants will be weaker when the business environment is less

6 We use TFP as shorthand for revenue based Total Factor Productivity. This will contain an element of the markup (see Hsieh and Klenow, 2009) but is likely to be correlated with quantity based TFP (see Bartelsman, Haltiwanger and Scarpetta, 2013). 
competitive and/or more distorted by regulatory frictions - which motivates our analysis of competition and regulation.

By using the plausibly exogenous variation within our dataset, we help to identify the causal effects of these factors on the adoption of structured management practices.

For product market competition, we undertake two strategies. First, we calculate the industry Lerner index and look at cross sectional and panel variation. Second, we exploit changes in exchange rates that differentially affect the plant's industry depending on which countries are competing in its output market. We find that product market competition increases the adoption of structured management practices, particularly at plants in the lower tail of the structured management distribution.

On business environment, we exploit both the location of plants around the border between "Right to Work" and non-"Right to Work" states and the location of firms' oldest surviving plants in multi-plant firms to identify impacts of business environment on management practices. We find "Right to Work" rules, which are a proxy for the state business environment - including reduced influence of labor unions as well as "pro-business" policies such as more flexible environmental and safety regulations (see Holmes, 1998) - seem to increase structured management practices around firing and promotions but seem to have little impact on other practices.

To investigate learning spillovers, we build on Greenstone, Hornbeck and Moretti's (2010) identification strategy using "Million Dollar Plants" - large investments for which both a winning county and a runner-up county are known. Comparing the counties that "won" the large, typically multinational plant versus the county that narrowly "lost," we find significant positive impacts on management practices, TFP and employment. Importantly, the positive spillovers only arise if the winning entrant was also a manufacturing plant, suggesting localized managerial spillovers tend to be mainly within the same sector (recall that the MOPS data solely relates to manufacturing plants).

Finally, to obtain causal impacts of education, we follow Moretti (2010) to use the quasirandom location of land-grant colleges as an instrument for local supply of more educated labor. We find large significant effects on management practices of being near a land-grant college with a range of controls for other local variations in population density, income and other county-level and firm-level controls. 
Our estimates imply that these four drivers account for around a third of the 90-10 between-plant spread of structured management practices. Although this is a non-trivial fraction, it leaves plenty of room for other determinants of these management practices.

The paper is structured as follows. In Section 2, we describe the management survey; in Section 3, we detail the variation of management practices across and between firms; and in Section 4, we outline the relationship between management and performance; in Section 5, we examine potential drivers of management practices. Finally, in Section 6 we conclude and highlight areas for future analysis.

\section{Management and Organizational Practices Survey}

The Management and Organizational Practices Survey (MOPS) was jointly funded by the Census Bureau and the National Science Foundation and was delivered as a mandatory supplement to the Annual Survey of Manufacturers (ASM). 7 The original design was based in part on a survey tool used by the World Bank and adapted to the U.S. through several months of development and cognitive testing by the Census Bureau.8 It was sent electronically as well as by mail to the ASM respondent for each establishment,9 which was typically the plant manager or financial comptroller. Most respondents (58.4\%) completed the survey electronically, with the remainder completing the survey by paper. Non-respondents were mailed a follow-up letter after six weeks if no response had been received. A second follow-up letter was mailed if no response had been received after 12 weeks. The first follow-up letter included a copy of the MOPS instrument. An administrative error occurred when merging Internet and paper collection data that caused some respondents to receive the first follow-up even though they had already responded. We exploit this accident to deal with measurement error in the management scores in Section 3.

\subsection{Measuring Management}

The survey contained 16 management questions in three main sections: monitoring, targets and

For more details see Buffington, Foster, Jarmin and Ohlmacher (2016).

See Buffington, Herrell and Ohlmacher (2016) for more information on the testing and development of the MOPS.

The Appendix provides more details on datasets. 
incentives, based on Bloom and Van Reenen (2007), which itself was based in part on the principles of continuous monitoring, evaluation and improvement from Lean manufacturing (e.g., Womack, Jones and Roos, 1990). The survey also contains questions on other organizational practices (such as decentralization) based on work by Bresnahan, Brynjolfsson and Hitt (2002) as well as some background questions on the plant and the respondent.

The monitoring section asked firms about their collection and use of information to monitor and improve the production process. For example, the survey asked, "How frequently were performance indicators tracked at the establishment?", with response options ranging from "never" to "hourly or more frequently." The targets section asked about the design, integration and realism of production targets. For example, the survey asked, "What was the time-frame of production targets?", with answers ranging from "no production targets" to "combination of short-term and long-term production targets." Finally, the incentives section asked about non-managerial and managerial bonus, promotion and reassignment/dismissal practices. For example, the survey asked, "How were managers promoted at the establishment?", with answers ranging from "mainly on factors other than performance and ability, for example tenure or family connections" to "solely on performance and ability." 10

In our analysis, we aggregate the results from these 16 questions into a single measure of "structured management." This management score is the unweighted average of the score for each of the 16 questions, where the responses to each question are first scored to be on a $0-1$ scale. Thus, the summary measure is scaled from 0 to 1 , with 0 representing an establishment that selected the category which received the lowest score (little structure around performance monitoring, targets and incentives) on all 16 management dimensions and 1 representing an establishment that selected the category that received the highest score (an explicit structured focus on performance monitoring, detailed targets and strong performance incentives) on all 16 dimensions.

\subsection{Sample and Sample Selection}

Overall, 49,782 MOPS surveys were successfully delivered, and 37,177 responses were received, yielding a response rate of $78 \%$, which is similar to the response rate of the main ASM survey. For

10 The full questionnaire is available on $\mathrm{http}: / / \mathrm{www} . c e n s u s . g o v / \mathrm{mcd} / \mathrm{mops} / \mathrm{how}$ the data are collected/MP10002_16NOV10.pdf 
most of our analysis, we further restrict the sample to establishments with at least 11 non-missing responses to management questions that also have positive value added, positive employment and positive imputed capital in the ASM. Table A1 shows how our various samples are derived from the universe of establishments.11

Table A2 provides more descriptive statistics on the samples we use for analysis. The mean establishment size is 167 employees and the median (fuzzed) is approximately 80. The average establishment in our sample has been in operation for 22 years, $44 \%$ of managers and $9 \%$ of nonmanagers have college degrees, $13 \%$ of workers are in unions, $42 \%$ of plants export, and $69 \%$ of plants are part of larger multi-plant firms. Finally, Table A3 reports the results for linear probability models for the different steps in the sampling process. We show that establishments that were mailed and responded to the MOPS survey are somewhat larger and more productive compared to those that did not respond, but these differences are quantitatively small.

\subsection{Performance Measures}

In addition to our management data, we also use data from other Census and non-Census data sets to create our measures of performance (productivity, profitability, innovation, and growth). We use establishment-level data on sales, value-added and labor inputs from the ASM to create measures of growth and labor productivity. As described in detail in the Appendix, we also combine capital stock data from the Census of Manufactures (CM) with investment data from the ASM and apply the Perpetual Inventory Method to construct capital stock at the establishment level, which we use to create measures of total factor productivity. For innovation, we use firmlevel data from the 2009 Business R\&D and Innovation Survey (BRDIS) on R\&D expenditure and patent applications by the establishment's parent firm (from the USPTO).

\section{Management Practices across Plants and Firms}

Figure 1 plots the histogram of plant management scores, which displays enormous dispersion.

11 Table A1 reports the results for linear probability models for the different steps in the sampling process. We show that establishments that were mailed and responded to the MOPS survey are somewhat larger and more productive compared to those that did not respond, but these differences are quantitatively small. 
While $18 \%$ of establishments have a management score of at least 0.75 , meaning they adopt $75 \%$ of the most structured management practices, $27 \%$ of establishments receive a score of less than 0.5 (that is, they adopt less than half the practices).

One important question is: to what extent do these variations in management practices across plant occur within rather than between firms? The voluminous case-study literature on management practices often highlights the importance of variations both within and between organizations, but until now it has been impossible to measure these separately due to the lack of large samples with both firm and plant variation. The benefit of the large MOPS sample is that we have multiple plants per firm, making this the first opportunity to evaluate variations within and between firms accurately.

Before decomposing the between-plant management dispersion into a within-firm component and a between-firms component, we need to address a major challenge: the bias induced by measurement error. Measurement error in plant-level management scores will inflate the plant-level variation and thus bias downwards the component of the overall plant-level variation we attribute to the firm-level component. Estimates in Bloom and Van Reenen (2007) from independent repeat management surveys (at the same point of time) imply that measurement error accounts for $25 \%$ of the variation in management score and $42 \%$ of the variation at the practices level, making this an important issue.

To address this challenge, we exploit a valuable feature of the 2010 MOPS survey, which is that approximately 500 plants from our baseline sample have two surveys filled out by different respondents.12 That is, for this set of plants, two individuals - for example the plant manager and plant comptroller - both independently filled out the MOPS survey.13 This is most likely because a follow-up letter was mailed to the plant in error that included a form and online login information, and an individual other than the original respondent received the letter. These double responses provide very accurate gauges of survey measurement error, because within a narrow three-month window we have two measures of the same plant-level management score provided by two independent respondents. From correlation analysis of the two sets of completed surveys, we find

12 For disclosure avoidance reasons, we cannot provide exact sample sizes, but this data is available through the Federal Statistical Research Data Centers.

13 In total, approximately 1,200 plants from the baseline sample completed the survey more than once, either once on paper and once online or twice on paper. Of these, about 500 provided a second response filled out by a different respondent. 
that measurement error accounts for $45.4 \%$ of the observed management variation across plants. 14 This measurement also turns out to be independent of any firm- or plant-level observable characteristic such as employment or the number of plants in the firm (see Appendix Table A4), and thus appears to be effectively white noise.

Armed with this estimate of $45.4 \%$ of the variation accounted for by measurement error, we can now decompose the remaining variation in the management score into the part accounted for by the firm and the part accounted for by the plant. To do this, we keep the sample of 16,50015 out of 31,793 plants in the sample that are in multi-plant firms with two or more plants in the MOPS survey. Although this sample only contains $44 \%$ of the overall sample, these are larger plants and account for $74 \%$ of output in the MOPS sample (so our decompositions here relate to firms accounting for about three quarters of US manufacturing output).

The first series in Figure 2 (blue diamonds) plots the share of the plant-level variation in the management score accounted for by the parent firm in firms with 2 or more plants after scaling by $(0.546=1-0.454)$ to account for measurement error. To understand this graph, first note that the top left point is for firms with exactly two plants. For this sample, firm fixed effects account for $90.4 \%$ of the adjusted R-squared in management variation across plants, 16 with the other $9.6 \%$ accounted for by variation across plants within the same firm. So, in smaller two-plant firm samples, most of the variation in management practices is due to differences across firms.

Moving along the $\mathrm{x}$-axis in Figure 2, we see that the share of management variation attributable to the parent firm declines as firm size rises. For example, in firms with 50-74 plants, the parent firm accounts for about $40 \%$ of the observed management variation, and in firms with 150 or more plants, the parent firm accounts for about $35 \%$ of the variation. Hence, in samples of plants from larger firms, there is relatively more within-firm variation and relatively less crossfirm variation in management practices.

14 Assuming the two responses have independent measurement error with standard deviation $\sigma^{\mathrm{M}}$, and defining $\sigma^{\mathrm{T}}$ as the true management standard deviation, the correlation between the two surveys will be $\sigma^{\mathrm{T}} /\left(\sigma^{\mathrm{T}}+\sigma^{\mathrm{M}}\right)$. Interestingly, this $45.4 \%$ share of the variation from measurement error is very similar to the $49 \%$ value obtained in the World Management Survey from second independent telephone interviews (Bloom and Van Reenen, 2010).

15 Note that because of clearance restrictions, many sample sizes have been rounded.

16 It is essential for this part of the analysis that the adjusted $\mathrm{R}^{2}$ on the firm fixed effects is not mechanically decreasing in the number of establishments in the firm. To alleviate any such concern, we simulated management scores for establishments linked to firms with the same sample characteristics as our real sample (in terms of number of firms and number of establishments in a firm), but assuming no firm fixed effects. We then verified - shown in Appendix Figure A2 - that indeed for this sample, the adjusted $\mathrm{R}^{2}$ is zero and does not show any pattern over the number of establishments in a firm. 
At least two important results arise from Figure 2. First, both plant-level and firm-level factors are important for explaining differences in management practices across plants, with the average share of management variation accounted for by firms being $58 \%$ (so $42 \%$ is across plants within the same firm). Second, the share of management practice variation accounted for by the parent firm is declining in the overall size of the firm, as measured by the number of establishments.

What explains the large fraction of within-firm variation in management practices? One likely explanation is that within a firm, different establishments operate in different environments - for example, different industries or locations, in which different management practices are appropriate. To evaluate this explanation, the second series in Figure 2 (green dots) repeats the analysis with one change: when we run the regressions of management on firm fixed effects (used to recover the adjusted $\mathrm{R}^{2}$ ), we control for the part of the management score that is explained by within firm/across plant industry and MSA variation.17 This essentially removes the within-firm share of variation in management that is explained by industry and geographical variation. There are two points to highlight from this exercise. First, by construction, the overall within-firm management variation is smaller, going down from $42 \%$ on average to $19 \%$. Second, the relation between size and within-firm variation is flatter, where we cannot reject the null that the withinfirm variation is similar for 10 and $150+$ plants firms. This is consistent with larger firms (those with more than 10 employees) operating across more industries and geographical regions, which accounts for their greater within firm spread in management practices.

We further explore these points in Table 1, reporting results from a regression of the withinfirm standard deviation of the management score on firm level characteristics. 18 Consistent with first series in Figure 2 (blue diamonds), columns (1) and (2) demonstrate that the standard deviation of management within a firm is increasing with the number of establishments in the firm, and that this relation is stronger for firms with 10 establishments or less. Column (3) shows that operating in more industries and over more locations are both correlated with a larger within-firm spread of

17 Specifically, the $\mathrm{R}^{2}$ regressions include now the linear projection of management from a regression of management on full sets of NAICS and MSA dummies (where for plants in areas without an MSA, the state is used), where the regression also includes firm fixed effects. The sample for this regression is identical in both series in Figure 2.

18 Our management score is bounded between 0 and 1 . To ensure our regressions are not exposed to a mechanical relation whereby better-managed firms show smaller standard deviation of management because their establishments are pushed towards the upper bound of the score, we control in all regressions for a 5 degree polynomial of average management at the firm (results are almost identical for 3, 4, 6, or 7 degree polynomial). 
management. Columns (4) and (5) are consistent with the results in the second series in Figure 2 (green dots): once controlling for the number of within-firm industries and locations, the relation between management spread and size weakens and becomes insignificant for firms with more than 10 manufacturing establishments. Columns (6)-(11) show that the within-firm spread of management is correlated with other factors in an intuitive way. Although we do not find a correlation between the spread of management and the spread of establishment age within the firm (column (6)), we find that the spread of management is larger for firms with a larger employment spread (column (7)).19 We also find a larger spread for firms with more ownership changes over the past one, two and three years (columns (8) to (10)), suggesting it takes at least three years after a firm acquires a new plant to change its management practices.20

\section{Management and Performance}

Given the variations in management practices noted above, an immediate question is whether these practices link to performance outcomes. In this section, we investigate whether these more structured management practices are correlated with five measures of performance (productivity, growth, survival, profitability, and innovation). Although there is good reason to think management practices affect performance, we do not necessarily attribute a causal interpretation to the results in the section. Instead, it suffices to think about these results as a way to establish whether this management survey is systematically capturing meaningful content rather than just statistical noise.

\subsection{Management and Productivity}

We start by looking at the relation between labor productivity and management. Suppose that the establishment production function is:

$$
Y_{i t}=A_{i t} K_{i t}^{\alpha} L_{i t}^{\beta} e^{\gamma X_{i t}} e^{\delta M_{i t}}
$$

19 Interestingly, in the MOPS survey, we also asked about the extent of decentralization of plant-level decisions over hiring, investment, new products, pricing and marketing and found this was also significantly higher in larger firms (see Aghion et al., 2015).

20 We have also checked for the correlation with 4- and 5-year ownership changes, finding decreasing point estimates with no statistical significance. 
where $\mathrm{Y}_{\text {it }}$ is real value added (output - materials), $\mathrm{A}_{\text {it }}$ is productivity (excluding management practices), $\mathrm{K}_{\mathrm{it}}$ denotes the establishment's capital stock at the beginning of the period, $\mathrm{L}_{\mathrm{it}}$ are labor inputs, $\mathrm{X}_{\mathrm{it}}$ is a vector of additional factors such as education, and $\mathrm{M}_{\mathrm{it}}$ is our management score.21 Management is an inherently multi-dimensional concept, so for this study we focus on a single dimension: the extent to which firms adopt more structured practices.22

Dividing by labor and taking logs we can rewrite this in a form to estimate on the data

$$
\log \left(\frac{Y_{i t}}{L_{i t}}\right)=\alpha \log \left(\frac{K_{i t}}{L_{i t}}\right)+(\beta+\alpha-1) \log \left(L_{i t}\right)+\gamma X_{i t}+\delta M_{i t}+f_{i}+e_{i t}
$$

where we have substituted the productivity term $\left(\mathrm{A}_{\mathrm{it}}\right)$ for a set of industry (or establishment or firm) fixed effects $f_{i}$ and a stochastic residual eit. Because we may have multiple establishments per firm, we also cluster our standard errors at the firm (rather than establishment) level.

In Table 2 column (1), we start by running a basic regression of labor productivity (measured as $\log$ (value added/employee)) on our management score without any controls. We find a highly significant coefficient of 1.272 , suggesting that every $10 \%$ increase in our management score is associated with a $13.6 \%(13.6 \%=\exp (0.1272))$ increase in labor productivity. To get a sense of this magnitude, our management score has a sample mean of 0.64 and a standard deviation of 0.152 (see the sample statistics in Appendix Table A2), so that a one standard-deviation change in management is associated with a $21.3 \%(21.3 \%=\exp (0.152 * 1.272))$ higher level of labor productivity (see also Table 3 ). We provide more detailed magnitudes analysis in sub-section 4.3.

In column (2) of Table 2, we estimate the full specification from equation (1) with capital intensity, establishment size and employee education, industry dummies and "noise controls" (for potential survey bias such as whether the form was filled out online or offline). This reduces the coefficient on management to about 0.5 . Even after conditioning on many observables, a key question that remains is whether our estimated OLS management coefficient captures a relation between management and productivity, or whether it is just correlated with omitted factors that affect the management score and the productivity measure.

Using the 2005 recall questions, matched to the 2005 ASM files, we can construct a two

21 We put the management score and $\mathrm{X}_{\mathrm{it}}$ controls to the exponential simply so that after taking logs we can include them in levels rather than logs.

22 The individual practices are highly correlated, which may reflect a common underlying driver or complementarities among the practices (see e.g., Brynjolfsson and Milgrom, 2013). In this exercise, we use the mean of the share of practices adopted, but other measures like the principal factor component or z-score yield extremely similar results. 
period panel of management, productivity and other controls, to at least partially address this concern over omitted factors. As long as the unobserved factors that are correlated with management are fixed over time at the establishment level (corresponding to $f_{i}$ in equation (1)), we can difference them out by running a fixed effect panel regression. Column (3) reports the results for the 2005-2010 pooled panel regression (including a 2010 time dummy).23 The coefficient on management, 0.298 , remains significant at the $1 \%$ level. Of course, this coefficient may still be upwardly biased if management practices are proxies for time-varying unobserved shocks. On the other hand, the coefficient on management could also be attenuated towards zero by measurement error, and this downward bias is likely to become much worse in the fixed-effect specification. 24

The rich structure of our data also allows us to compare firm-level versus establishmentlevel management practices. In particular, by restricting our analysis to multi-establishment firms, we can check whether there is a correlation between structured management and labor productivity within a firm. When including a firm fixed effect in the cross section of plants, the coefficient on management is identified solely off the variation of management and productivity across plants within each firm in 2010. Column (4) of Table 2 shows OLS estimates for the sub-sample of multiestablishment firms with firm-effects. The within-firm management coefficient of 0.233 is highly significant. Hence, even within the very same firm, when management practices differ across establishments, we find large differences in productivity associated with these variations in management practices. This is reassuring since we have shown that there is a large amount of management variation across plants within the same firm.

So far, we have established a strong correlation between labor productivity and the adoption of management practices. It is likely that this relation is somewhat contingent on the firm's environment, and that the adoption of particular management practices is more important in some contexts than in others. To investigate this heterogeneity, we estimate the specification in column (2) of Table 2 for the 86 four-digit manufacturing NAICS categories. Figure 3 plots the

23 Note that the sample is smaller, because we now require non-missing controls also for 2005. In particular, we have to drop plants that entered after 2005, and plants that were not part of the previous ASM rotating panel (the panel is revised every 5 years, at years ending 4 and 9 ).

24 There is certainly evidence of this from the coefficient on capital, which falls dramatically when establishment fixed effects are added, which is a common result in the literature. 
smoothed histogram of the 86 regression coefficients.25 The distribution is centered on 0.5 , which reassuringly is the coefficient from the pooled regression. Ninety-two percent of establishments operate in industries with a positive labor productivity-management relation.

Nevertheless, Figure 3 demonstrates that indeed there is a lot of heterogeneity, and an F-test for the null of no difference across industries is easily rejected ( $p$-value $<0.001$ ). These findings suggest that structured management is differentially important across environments as one would expect. We leave a more thorough investigation of the reasons for this heterogeneity for future research, but we did examine whether structured management was less important for productivity in sectors where innovation mattered a lot (e.g. high industry intensities of R\&D and/or patenting), as perhaps an over-focus on productive efficiency could dull creativity. Perhaps surprisingly, we found that the productivity-management was actually stronger in these high tech industries, perhaps implying that rigorous management of $\mathrm{R} \& \mathrm{D}$ labs is as important as production plants.

\subsection{Management and Other Performance Measures (Growth, Profitability and Innovation)}

In column (5) of Table 2, we examine another performance measure: employment growth between 2010 (the year of the MOPS data) and 2013 (the last year of the ASM panel). Establishments with more structured management practices grew significantly faster in future years.26 Column (6) adds the 2010 level of $\mathrm{TFP}_{27}$ to the right-hand side of the employment growth equation and not surprisingly finds that this also has predictive power for future employment growth. Interestingly, adding TFP does not substantially diminish the coefficient on management, suggesting that both TFP and management provide predictive power for future employment growth. Moreover, we also see that the t-statistic on management (about 10) is more than double the t-statistic on TFP (about 4), which highlights how informative the management score is for plant performance.

Columns (7) and (8) of Table 2 perform a similar analysis for a plant's exit probability between 2010 and 2013, and we again find that the management score is highly predictive of future performance. In terms of magnitudes, the unconditional probability of exit between 2010 and 2013

25 To comply with Census disclosure avoidance requirements, we do not report the actual coefficients industry by industry, but a smoothed histogram.

26 To make interpretation and comparison between management score and TFP easier, both management and TFP are normalized by their standard deviation in columns (5)-(8).

27 This is constructed following the standard approach in Foster, Haltiwanger and Krizan (2001) - see Appendix A. 
is $7 \%$ in our sample, and a one standard deviation increase in management is associated with a 2 percentage point decline in this exit probability (i.e., a 29\% drop in the exit rate). For comparison, a one standard deviation increase in TFP is associated with a 0.8 percentage point decline in exit probability (an 11\% drop in the exit rate). Column (9) looks at profitability (operating profits divided by sales), and finds that establishments with higher management scores are significantly more profitable. Finally, Column (10) looks at a classic measure of innovation - R\&D spending per employee - and finds a strongly positive significant correlation with management for a sample of MOPS plants that match the Business R\&D and Innovation Survey.28

We also ran a series of other robustness tests on Table 2, such as using standardized zscores (rather than the 0-1 management scores), dropping individual questions that might be output-related and using ASM sampling weights, and we found very similar results.

A non-parametric description of these management and plant performance correlations is shown in Figure 4. This confirms the robust positive and broadly monotonic relationship between structured management and productivity, profitability, growth, exporting, R\&D and patenting reported in the regression analysis.29 Figure A1 cuts the data in another way, plotting the size of establishments and firms against their management scores, showing a continuous positive relationship from sizes of 10 employees upwards. These panels show that both establishment and firm management scores are rising in size until they reach about 5,000 employees, after which the relationship levels off. This difference is also quantitatively large. A firm with 10 employees has a management score of 0.5 compared to 0.7 for a firm with 1,000 employees. This is comparable to moving from approximately the $20^{\text {th }}$ percentile to the $70^{\text {th }}$ percentile of the management score distribution.

Finally, while most of our analysis in this section has focused on within-industry management-performance relationships, a similar positive association between management and firm performance is observed across industries and locations. Appendix Table A5 replicates columns (5) and (7) of Table 2 examining performance, this time first collapsing the data by taking

28 Running the same regression on another measure of innovation, $\log (1+$ patents $)$, we find a similarly significant coefficient (standard error) of $0.510(0.101)$.

29 Under the Milgrom and Roberts (1990) model of complementarity organizational practices we might have expected a more convex relationship, with large rises in performance only visible in plants that adopt a large number of complementary practices (e.g. Ichniowski et al, 1997; Meagher and Strachan, 2016). Our evidence suggests that such complementarities may be second order or that the data is too coarse to identify these effects. 
means over the 471 NAICS industry codes (columns (1) and (2)), and then by collapsing the data at the county level (columns (3) and (4)). The management-performance relation remains large and statistically significant - industries and regions with higher management scores have significantly higher growth and rates of survival.30 This is an important point for motivating the analysis conducted in Section 5, where industry and geography provide variation for the identification of management drivers.

\subsection{Magnitudes of the Management and Productivity Relationship}

To get a better sense of the magnitudes of the management-productivity relation, we compare management to other factors that are commonly considered important drivers of productivity: R\&D, information technology (IT) and human capital. We focus on these three because they are leading factors in driving TFP differences (e.g., discussed in detail in the survey on the determinants of productivity in Syverson, 2011), and because we can measure them well using the same sample of firms used for the analysis of the management-productivity link. In particular, we ask how much of the 90-10 TFP spread can be accounted for by the 90-10 spread of management, R\&D expenditure, IT investment per worker, and human capital (measured as the share of employees with a college degree).

Columns (1)-(4) of Table 3 report the results from firm-level regressions of TFP on those factors. To obtain an aggregate firm-level TFP measure, the dependent variable is calculated as industry-demeaned TFP at the firm level, where the establishments within a firm are weighted by total value of shipments.31 The bottom row of column (1) shows that the 90-10 spread in management accounts for about $18 \%$ of the spread in TFP. In columns (2) to (4) we examine R\&D, IT and skills and find these measures account for $17 \%, 8 \%$ and $11 \%$ of the $90-10$ TFP gap, respectively. Column (5) shows that the role of management remains large in the presence of the other factors, and that jointly these can account for about a third of the 90-10 spread in TFP. Given estimates that about 50\% of firm-level TFP is measurement error (see Collard-Wexler, 2013 and

\footnotetext{
30 We focused on employee growth and survival, because they are more comparable across industries. Results also were significant for other measures like value-added per employee, but these could be concerns over cross-industry and region variations arising due to technological and price level variations.

31 We run the regression at the firm level, because R\&D is only measured at the firm level, making it easier to compare between factors. To obtain the firm-level measure, we weight the right-hand variables by their plant's share of total shipments (exactly as we do for the dependent variable).
} 
Bloom et al., 2016),32 this indicates these four factors - management, innovation, IT and human capital - can potentially account for about two-thirds of the true (non-measurement error) variation in TFP. Moreover, the results in Table 3 also highlight that management practices can account for a relatively large share of this explanatory power for firm-level TFP. 33

\section{Drivers of Management Practices}

The previous literature on management has pointed to a wide variety of potential factors driving management practices. We focus on four - product market competition, business environment, knowledge spillovers and education - for which we have good measures as well as some degree of causal identification.

\subsection{Product Market Competition}

One of the challenges in evaluating the impact of competition on management is measuring competition. One of the measures of competition most commonly used by economists is the Lerner index,34 which is defined as ( 1 - marginal price-cost markup). In practice, the Lerner measure is defined as the average (rather than marginal) markup, measured at the industry level over a recent time period; for example, Aghion et al. (2005) used the average rate of profits/sales over the prior five years. In our evaluation, we use gross profits (shipments less material costs and wage costs) to sales ratio in 2007, which was the most recent year of the five-yearly economic census. In Table 4, using this Lerner index at the NAICS six-digit level without any controls (column (1)) and with three-digit industry NAICS fixed effects and full controls (column (2)), we find competition is significantly correlated with more structured management practices. In column (3) we also include

32 We make this calculation under the assumption that measurement error in TFP is not correlated with the factors in Table 3.

33 One obvious concern, however, is causality, which is hard to address with this dataset. In related work, Bloom et al. (2013b) run a randomized control trial varying management practices for a sample of Indian manufacturing establishments with a mean employment size of 132 (similar to our MOPS sample average of 167). They find evidence of a large causal impact of management practices towards increasing productivity, profitability and firm employment. Other well-identified estimates of the causal impact of management practices - such as the RCT evidence from Mexico discussed in Bruhn, Karlan and Schoar (2016) and the management assistance natural experiment from the Marshall plan discussed in Giorcelli (2016) - find similarly large impacts of management practices on firm productivity.

34 The other popular measure is the Herfindahl index, but in manufacturing this is problematic because many competitors are international and our data only covers U.S. firms. 
firm fixed effects, so we are examining changes in management practices across plants within the same firm against the differences in their Lerner indices (if the plants operate in different industries), and we find a positive but insignificant relationship.

In columns (4) to (6) of Table 4, we examine changes in management practices between 2005 and 2010 against changes in the Lerner index between 2007 and 2002 (the most recent Census years preceding the management time dates). Using these difference estimators helps to strip out any time-invariant differences in the measurement of profitability across industries. In all specifications, we find increases in competition are associated with increases in the management score conditional on surviving. Note that column (6) is a particularly demanding specification as we are allowing for firm specific trends, identifying the competition effect solely from differences in the competition shock across plants within the same firm.

Because changes in the Lerner index could still be endogenous, we consider a more exogenous shock to competition in columns (7) to (9), which follows Bertrand (2004) in constructing "industry-level exchange rates." Although changes in exchange rates do not vary across industries, the effects of currency changes will be more salient to the customers of industries that are buying more imports from the country whose value (for example) has depreciated against the dollar. Thus, we calculate the industry-specific import shares from each country and multiply this by the change in that country's exchange rate. This creates industry-by-year exchange rates (see Appendix for details). We find that as the U.S. dollar appreciates, increasing domestic competition -- the measure of management practices of our U.S. plants -- significantly increases in all three specifications: without controls, with full firm and industry controls, and with a full set of firm fixed effects. Given that these differences in exchange rates are driven by factors typically external to the industry - such as country-level economic cycles, interest rates and other macro shocks - this provides strong causal evidence for a positive impact of competition on improving management practices.

In Table 5, we examine the relationship between management and competition for different quantiles of the management score. In column (1), we replicate column (1) of Table 4. Columns (2)-(6) report the results from quantile regressions for different quantiles of the conditional management score $(0.1,0.25,0.5,0.75$ and 0.9$)$. We find there is a much stronger relationship between competition and management at the lower part of the management distribution. The 
coefficient on competition is five times as large at the $10^{\text {th }}$ percentile of the conditional management distribution as at the $90^{\text {th }}$ percentile. These results are consistent with a combination of selection and improvement of firms through competition, which acts in particular to increase the management practices of low scoring plants or to force them to exit.

\subsection{Business Environment}

For understanding the variation in management across plants, the business environment in which plants operate is another often-mentioned driver of management practices. We use "Right to Work" (RTW) regulations, which are state-level laws prohibiting union membership or fees from being a condition of employment at any firm. Holmes (1998) finds that RTW laws likely proxy for other aspects of the state business environment, including "pro-business" policies that could benefit manufacturers, such as looser environmental or safety regulations, subsidies for manufacturing plant construction, and tax breaks that disproportionately benefit manufacturers. At the time of the MOPS survey, 22 states had RTW laws in place, mostly in the South, West and Midwest, with another six states having introduced them since then.35

In Table 6, we estimate the impact of RTW laws on management practices in firms. To try to obtain a causal estimate, we follow the approach taken by Holmes (1998) who looked at business regulations and state employment. We compare plants in counties that are within 50km (about 30 miles) of state borders that divide states with different RTW rules. In column (1), the regression sample is the 5,143 plant-border pairs within $50 \mathrm{~km}$ of a state-border between two states with different RTW regulations. We see that after controlling for industry and border fixed effects, the plants on the RTW side of the border have significantly higher management scores.36

One explanation for this result is that RTW regulations make it easier for firms to link hiring, firing, pay and promotion to employees' ability and performance, thereby increasing their structured management scores. An alternate explanation is that plants with more structured management practices sort onto the RTW side of the border, possibly because of these RTW regulations or other correlated "pro-business" factors. In column (2) we look at plants in the least-

35 These are Indiana and Michigan in 2012, Wisconsin in 2015, West Virginia in 2016, and Kentucky and Missouri in 2017. We will examine Indiana, Michigan, and Wisconsin in the 2015 MOPS survey wave when the data becomes available.

36 These results are also significant when comparing directly between all plants in RTW vs non-RTW states. 
tradable quartile of industries - industries like cement, wood pallet construction or bakeries, defined in terms of being in the bottom quartile of geographic concentration - that are the least likely to sort on location because of high transport costs.37 Again, we find RTW states have significantly higher management scores within this sample of relatively non-tradable products for which selecting production location based on "business-friendly" conditions is particularly hard.

As an alternative approach, column (3) takes the sample of all firms with plants in both RTW and non-RTW states, and then divides them by whether the oldest surviving plant in the firm is located in a RTW state or not. The idea here is that if the oldest plant in a firm is in a RTW state, the firm management practices are likely to be more tailored to this regulatory environment because of persistence of management practices within firms over time. That is, if the firm was likely founded in a RTW state, and if management practices are somewhat sticky over time within firms, we should see more recently opened plants inheriting some of the practices from the founding plant. Indeed, we see in column (3) that firms with their oldest plants in a RTW state have significantly higher management scores than those with their oldest plants in a non-RTW state, even after including industry and state fixed-effects. This means, for example, that if two plants from different firms were both based in California, but one firm had its oldest plant in Texas (a RTW state) and the other in Massachusetts (a non-RTW state), the plant from the Texan firm would typically have a higher management score. In column (4), rather than using the oldest plant, we measure exposure to RTW by the location of the firm's headquarter plant 38 and again find similar results.

In column (5) of Table 6 we use a slightly different cut of the data, focusing on the types of management practices that RTW regulations are likely to support (in part by reducing the influence of unions39) - the four questions on the connection between employee ability and performance and promotions and dismissals. We find a large positive and significant coefficient. In column (6) we look at the other 12 MOPS questions on monitoring and targets, which are much less directly

37 Our industry geographic concentration indexes are calculated following Ellison and Glaeser (1997) using the 2007 Census of Manufacturers.

38 The headquarter plant (HQ) is defined as being the establishment in the firm with a NAICS code 551114 (which is "corporate, subsidiary and regional managing offices"). If no such establishment exists, the HQ is defined as the largest plant. Results are robust to only defining the HQ using the largest plant, or only using the sample for which a plant with NAICS code 551114 exists.

39 Running a regression like column (2), but using a 0/1 dummy for the plant being unionized, generates a highly significant coefficient (standard-error) of $-0.056(0.016)$. 
related to RTW regulations, and find a positive coefficient but small in magnitude and statistically insignificant.

\subsection{Learning Spillovers}

Do structured management practices "spill over" from one firm to another, as would happen if there were learning behavior? To get closer to a causal effect, we study how management practices in particular counties in the U.S. change when a new, large and typically multinational establishment, likely to have higher management scores, is opened in the county.40 A key challenge, of course, is that such counties are not selected at random. It is in fact very likely that counties that "won" such large multinational establishments are very different than a typical county in the U.S. To overcome this issue, we compare counties that "won" the establishment with the "runner-up" counties that competed for the new establishment (see the Appendix for more details about data construction). This approach is inspired by Greenstone, Hornbeck and Moretti (2010), who study the effect of agglomeration spillovers by looking at productivity of winners and runnerup counties for Million Dollar Plants (MDPs).

Before looking at the results, we check that the observable characteristics for winners and runner-up counties are balanced (see Table A6). We look at all MDPs pooled in column (1) and then separately for manufacturing and non-manufacturing MDPs in the next two columns. Of the 52 coefficients, only three are significant. Importantly, there are no significant differences in 2000 to 2005 trends in employment and productivity between winners and runner-ups.

Table 7 contains the spillover results, split into two panels examining all MDPs in Panel A and with manufacturing and non-manufacturing split out in Panel B. In column (1) of Panel A, we see the basic result that in counties where an MDP was opened between 2005 and 2010, structured management practice scores significantly increased compared to the runner-up county. The magnitude of the coefficient is moderately large - winning a large, typically multinational plant is associated with an improvement of management practices of about 0.017 points, which is around 0.1 standard deviations. Column (2) includes a fuller set of establishment control variables and

40 Note that we do not choose these plant openings using Census data, but using public data only (see more details in the Appendix). In fact, to ensure the confidentiality of plants in our sample, we do not report whether these plants even appear in our data or not. 
shows similar results. Columns (3) and (4) look at the change in measured TFP associated with the entry of an MDP and finds an increase in productivity consistent with the increasing management score, albeit one that is not statistically significant. Finally, columns (5) and (6) look at employment as an outcome, and shows a significant increase in firm size following MDP entry, as we would expect from the productivity results.41

In Panel B of Table 7, we split the MDPs into those that are in the manufacturing sector and those that are in the non-manufacturing sector. We find the positive effects of MDPs on management, TFP, and employment all arise from the manufacturing MDP openings and not nonmanufacturing MDP entry. Given that the left hand side outcomes are solely from the MOPS manufacturing plants this is exactly what we would expect - management practices improvements (and hence productivity and employment) will spill over more rapidly and effectively within sectors (from manufacturing MDPs to incumbent manufacturing plants) than across sectors (from non-manufacturing MDPs to incumbent manufacturing plants). Most manufacturing MDPs are in industries like automotive, aerospace and machinery production, in which modern Lean Manufacturing practices are highly refined and are applicable across the manufacturing sector. In services, the plants span a wide range of sectors - call centers, health clinics and warehouses - so the management practices spillovers on to the domestic manufacturing plants in the MOPS database used here are likely to be far more muted.

One potentially surprising result is the negative spillovers of non-manufacturing MDPs on the measured TFP of our manufacturing plants. The likely reason for this is that the opening of large establishments will increase the prices of local inputs (a "congestion effect" as found by Greenstone, Hornbeck and Moretti, 2010). Because our TFP measure uses industry-wide factor shares to weight the inputs, these higher county-specific inputs prices bias measured TFP downwards. For example, we use national deflators for the total costs of capital structures (buildings being a component of the plant's capital stock). If the MDP increases local commercial rents (the "price" of structures) in the county, it will appear as if the plant is using a higher volume of capital than it actually does. Thus, for a given level of output, it will have lower measured TFP. This biases the coefficients on both the manufacturing and non-manufacturing MDP downwards,

41 Note that this excludes the MDP plant itself by construction, and is instead measuring a rise in employment in preexisting incumbent plants. 
so that the MDP coefficient in the TFP equation is the net impact of this measurement bias plus any real spillover. Note that this does not affect the management equation because it is independently measured, which is another advantage of having management data as well as TFP.42

Appendix B states these propositions more formally. In particular, if we assume a model in which the congestion effects are equal for all MDPs but where only manufacturing plants generate learning spillovers, then a manufacturing MDP is associated with about a $19 \%$ increase in productivity using column (4) of Table 7.43

In summary, we see strong evidence for the impact of opening of large, typically multinational plants on the management, productivity and employment of pre-existing local manufacturing plants (but not for the opening of non-manufacturing plants). This highlights the importance of localized within-industry learning spillovers.

\subsection{Education}

The final driver we investigate is the role of education in shaping firm-level management practices. In Bloom and Van Reenen (2007), education was the explanatory variable for management with the largest t-statistic, but because of the lack of any exogenous variation in firm-level education, it was hard to make a causal interpretation. In this paper, we combine the county-level information on the location of MOPS plants across the U.S. with the quasi-random location of Land Grant Colleges (LGCs) across counties to construct an instrument for the local supply of educated employees. This instrument builds on the work of Moretti (2004), who uses the quasi-random allocation of land-grant colleges, which were created by the Morrill Acts of 1862 and 1890 and typically located in large empty plots of land in the late 1800 s, to examine the impact of education on local productivity and wages.44

Column (1) of Table 8 reports an OLS regression of plant-level management practices on

42 Another concern is that MDPs may reduce mark-ups through a product market competition effect, which will be reflected in lower measured revenue-based TFP ("TFPR" is all we have here). This is unlikely to be the cause of the negative coefficient, however, because our dependent variable is TFPR for manufacturing plants. Nonmanufacturing MDPs are not competing in the same output markets as manufacturing plants, so it is hard to see why they should generate a negative effect on mark-ups and TFPR whereas manufacturing MDPs do not.

43 The share of capital in value added is about $30 \%$ on average, so using the results in Appendix B, the pure learning spillover effect is $0.17=0.106+(0.3 * .184)$ and $(\exp (0.17)-1) * 100=19 \%$.

44 We match the land grant college locations to metropolitan areas in the U.S. For the list of land grant colleges, we rely on the list in Moretti (2004) as well as the lists in the appendix to Nevins (1962). 
a dummy for whether the county contains an LGC, plus controls for population density and local unemployment rate (as controls for regional-level economic development), alongside industry and state fixed-effects and a range of basic plant-level controls (e.g., size, age, etc.). There is a large and significant coefficient on LGCs, suggesting that plants within counties that have an LGC have significantly higher management scores. Interestingly, if we split this sample by the industry median skill level, the relationship is larger and significant in the high-skill industries (where educational supply is likely to be more important) compared to the lower-skill industries.45 In column (2), we run a very exacting test by including firm fixed-effects, comparing across plants within the same firm, and we find that those located near LGCs have significantly higher management scores. This is important in light of our earlier results in Table 1 showing the importance of between-plant, within-firm effects.

In column (3) of Table 8, we look at the relationship between plant-level management practices and a county-level educational measure, which is the share of 25-60 year olds with a BA degree, and find a large, positive and significant coefficient. In column (4), we instrument local college graduate share with the existence of an LGC. This specification relies on the exclusion restriction that the impact of LGCs is solely through the supply of educated workers, rather than directly through, for example, executive education. Although this is a strong assumption, it is interesting that the coefficient on county education rises substantially.

Hence, in summary, the increased supply of college graduates seems to lead to more structured management practices, even after controlling for local economic development, suggesting a more direct route for higher-educated employees to lead to more structured management practices.

\subsection{Quantification}

In this subsection, we attempt a rough quantification the impact of the four drivers we examined. To do this, we take the coefficients from our preferred baseline specifications for each driver, and we scale the coefficient by that driver's 90-10 variation to get an implied 90-10 variation for

45 A coefficient (standard error) of $0.614(0.285)$ in high skilled industries compared to $0.438(0.314)$ in the low skilled industries. To define high skill and low skill industries, we calculate the average skill by industry using the "percentage with degree" variables, which are collected in MOPS in our sample. We define high skill industries as those with above median industry average and low skill industries as below median. 
management. We do this for each of the four drivers individually and then sum up the total to get an approximate combined magnitude, noting that any positive covariance of these drivers would cause an overestimate of the share of total management variation they account for, while a negative covariance would cause an underestimate.46 The management 90-10 we are trying to explain is defined as the observed 90-10 in the data - which is 0.385 (see Table A2) - scaled by the share of management variation that is estimated to be real (rather than measurement error), which is $54.6 \%$, as discussed in Section 3.

Our quantification exercise is clearly approximate, because there are numerous assumptions built into it,47 so the values should be taken as a rough indication of the relative importance of these drivers rather than exact values. With this in mind, we see in Table 9 that variations in competition, business regulations and spillovers account for something like $5 \%$ to $10 \%$ of the variation in management practices. Variations in education appear to account for a larger share at around 15\%, which interestingly matches the broad results in Bloom and Van Reenen (2007) in their Table VI, where they also find education measures have the largest explanatory role for management. Moreover, collectively these drivers account for over a third of the variation in management practices, suggesting they are collectively important but that other drivers of management are likely to play an important role.

\section{Conclusions and Future Research}

This paper analyzes a recent Census Bureau survey of structured management practices in over 30,000 plants across the U.S. Analyzing these data reveals large variation in management practices across plants, with strikingly about $40 \%$ of this variation being across plants within the same firm. This within-firm/across-plant variation in management cannot easily be explained by many classes

46 Unfortunately, we cannot run a regression with all four drivers in simultaneously, because the samples are nonoverlapping. For example, the identification strategy underlying knowledge spillovers means we restrict to "winner" and "loser" counties for MDPs whereas the business environment analysis restricts the sample to the borders of RTW and non-RTW states.

47 For example, assumptions that our results for each driver are causal, that the 90-10 for each driver matches up to the same population for the 90-10 for the management data, that for our total the drivers are orthogonal to each other, and that the measurement error share of the management for the 90-10 is the same as for the whole sample. Despite these caveats, we think it is useful to get a rough magnitude for the role of these drivers, with our results indicating they appear to play a substantial role (e.g., greater than $10 \%$ combined) but do not explain the large majority of management variation (e.g., less than $75 \%$ combined). 
of theories that focus on characteristics of the CEO, corporate governance or ownership (e.g., by family firms or multinationals) because these would tend to affect management across the firm as a whole.

These management practices are tightly linked to performance, and they account for about a fifth of the cross-firm productivity spread, a fraction that is as large as or larger than technological factors such as R\&D or IT. Examining the drivers of these management practices, we uncover four factors that are important for increasing the degree of implementation of structured management practices: product market competition, state business environment (as proxied by "Right to Work" laws), learning spillovers from the entry of Million Dollar Plants, and education.

Although all of these drivers are qualitatively important, their quantitative size is not enormous, with our estimations suggesting they collectively account for about a third of the variation in management practices. This leaves ample room for new theory, data and designs to help understand one of the oldest questions in economics and business: why is there such large heterogeneity in management practices?

\section{Bibliography}

Aghion, Philippe, Nicholas Bloom, Richard Blundell, Rachel Griffith and Peter Howitt, (2005), "Competition and Innovation: An Inverted-U Relationship," Quarterly Journal of Economics, 120(2), 701-728.

Aghion, Philippe, Nicholas Bloom, Brian Lucking, Raffaella Sadun and John Van Reenen, (2015), "Growth and Decentralization in Bad Times," Stanford mimeo.

Argote, Linda, Sara Beckman and Dennis Epple (1990) "The Persistence and Transfer of Learning in Industrial Settings" Management Science, 36(2) 140-154

Bartelsman, Erik, John Haltiwanger, and Stefano Scarpetta (2013), "Cross Country Differences in Productivity: The Role of Allocation and Selection." American Economic Review, 103(1): 305-334.

Bertrand, Marianne, (2004), "From the Invisible Handshake to the Invisible Hand? How Import Competition Changes the Employment Relationship," Journal of Labor Economics, 22(4), 723 765.

Bloom, Nicholas, Erik Brynjolfsson, Lucia Foster, Ron Jarmin, Itay Saporta-Eksten, and John Van Reenen, (2013), "Management in America," Census Bureau Center for Economic Studies 
Working Paper No. 13-01.

Bloom, Nicholas, Benn Eifert, Aprajit Mahajan, David McKenzie, and John Roberts, (2013b),

'Does Management Matter? Evidence from India,' Quarterly Journal of Economics, 128(1), $1-51$.

Bloom, Nicholas, Max Floetotto, Nir Jaimovich, Itay Saporta-Eksten and Stephen Terry, (2016), "Really Uncertain Business Cycles," Stanford mimeo

Bloom, Nicholas, Raffaella Sadun and John Van Reenen, (2016), "Management as a Technology," NBER Working Paper No. 22327

Bloom, Nicholas and John Van Reenen, (2007), "Measuring and Explaining Management Practices Across Firms and Countries," Quarterly Journal of Economics 122(4), 1351-1408

Bloom, Nicholas and John Van Reenen. 2010. "Why Do Management Practices Differ across Firms and Countries?" Journal of Economic Perspectives, 24(1): 203-24.

Bresnahan, Timothy F., Erik Brynjolfsson, and Lorin M. Hitt. "Information Technology, Workplace Organization, and the Demand for Skilled Labor: Firm-Level Evidence." Quarterly Journal of Economics 117(1) (2002): 339-376.

Bruhn, Miriam, Dean Karlan and Antoinette Schoar, (2016), “The Impact of Consulting Services on Small and Medium Enterprises: Evidence from a Randomized Trial in Mexico," forthcoming, Journal of Political Economy.

Brynjolfsson, Erik, and Paul Milgrom. (2013) "Complementarity in Organizations" in Robert Gibbons and John Roberts (eds) Handbook of Organizational Economics, 11-55Princeton: Princeton University Press.

Buffington, Catherine, Lucia Foster, Ron Jarmin and Scott Ohlmacher (2016), "The Management and Organizational Practices Survey (MOPS): An Overview," Census Bureau Center for Economic Studies Working Paper No. 16-28.

Buffington, Catherine, Kenny Herrell and Scott Ohlmacher (2016), "The Management and Organizational Practices Survey (MOPS): Cognitive Testing," Census Bureau Center for Economic Studies Working Paper No. 16-53.

Chew, W., Kim Clark, and Tim Bresnahan (1990), "Measurement, Coordination and Learning in a Multi-plant Network" in Robert Kaplan. Measures for Manufacturing Excellence, Boston: Harvard Business School Press

Collard-Wexler, Allan, (2013), "Demand Fluctuations in the Ready-Mix Concrete Industry" Econometrica," 81(3) 1003-1037

Ellison, Glenn and Edward L. Glaeser, (1997), "Geographic Concentration in U.S. Manufacturing Industries: A Dartboard Approach," Journal of Political Economy, 105(5).

Foster, Lucia, John Haltiwanger and C.J. Krizan, (2001), "Aggregate Productivity Growth: Lessons from Microeconomic Evidence," New Developments in Productivity Analysis, NBER, University of Chicago Press.

Freeman, Richard and Katheryn Shaw (2009) International Differnces in the Business Practices and Productivity of Firms, Chicago: Chicago University Press.

Gibbons, Robert, and Rebecca Henderson. (2013), "What Do Managers Do? Exploring Persistent Performance Differences among Seemingly Similar Enterprises.” in Robert Gibbons and John Roberts (eds) Handbook of Organizational Economics, 680-731, Princeton: Princeton University Press.

Giorcelli, Michela, (2016), “The Long-Term Effects of Management and Technology Transfer: 
Evidence from the US Productivity Program," UCLA mimeo.

Greenstone, Michael, Richard Hornbeck and Enrico Moretti, (2010), "Identifying Agglomeration Spillovers: Evidence from Winners and Losers of Large Plant Openings," Journal of Political Economy 118(3): 536-598.

Halac, Marina and Andrea Prat, (2016) "Managerial Attention and Worker Engagement," American Economic Review, 106(10): 3104-3132

Hsieh, Chiang-Tai and Pete Klenow (2009) "Misallocation and Manufacturing TFP in China and India." Quarterly Journal of Economics, 124(4): 1403-1448.

Holmes, Thomas J., (1998), "The Effect of State Policies on the Location of Manufacturing: Evidence from State Borders," Journal of Political Economy 106(4): 667-705.

Ichniowski, Casey, Kathryn Shaw, and Giovanna Prennushi. "The effects of human resource management practices on productivity: A study of steel finishing lines." American Economic Review (1997): 291-313.

Meagher, K. and Strachan, R. (2016) "Evidence on the Non-Linear Impact of Management" Australian National University mimeo

Milgrom, Paul and John Roberts (1990) "The Economics of Modern Manufacturing: Technology, Strategy, and Organization”, American Economic Review, 80(3), 511-28.

Moretti, Enrico, (2004), "Estimating the Social Return to Higher Education: Evidence from Longitudinal and Repeated Cross-Sectional Data," Journal of Econometrics, 121, 1-2: 175212

Nevins, Allan, (1962), The State Universities and Democracy, University of Illinois Press, Urbana, IL.

Schmalensee, Richard (1985), "Do Markets Differ Much” American Economic Review 75(3), $341-351$

Syverson, Chad, (2011), “What Determines Productivity?” Journal of Economic Literature, 49(2), 326-365.

Walker, Francis (1887) “The Source of Business Profits." Quarterly Journal of Economics. 1(3): 265-288.

Womack, James, Daniel Jones and Daniel Roos, (1991), The Machine that Changed the World, Simon and Schuster Inc: New York. 
Table 1: Within Firm (and across plant) Variation in Management

\begin{tabular}{|c|c|c|c|c|c|c|c|c|c|c|c|}
\hline \multicolumn{12}{|c|}{ Dependent Variable: Standard Deviation (Std Dev) of Management Spread within Firm } \\
\hline & (1) & (2) & (3) & (4) & (5) & (6) & (7) & (8) & (9) & $(10)$ & $(11)$ \\
\hline $\begin{array}{l}\text { Number of Manufacturing } \\
\text { Establishments (in logs) }\end{array}$ & $\begin{array}{c}0.959 * * * \\
(0.091)\end{array}$ & & & $\begin{array}{c}0.202 \\
(0.176)\end{array}$ & & & & & & & \\
\hline $\begin{array}{l}\text { Number of Manufacturing Est. } \\
\text { X (10 establishments or smaller) }\end{array}$ & & $\begin{array}{l}1.37 * * * \\
(0.231)\end{array}$ & & & $\begin{array}{l}0.56^{* *} \\
(0.284)\end{array}$ & $\begin{array}{l}0.562^{* *} \\
(0.284)\end{array}$ & $\begin{array}{l}0.473^{*} \\
(0.287)\end{array}$ & $\begin{array}{l}0.593^{* *} \\
(0.283)\end{array}$ & $\begin{array}{c}0.607 * * \\
(0.283)\end{array}$ & $\begin{array}{l}0.594 * * \\
(0.283)\end{array}$ & $\begin{array}{l}0.517^{*} \\
(0.286)\end{array}$ \\
\hline $\begin{array}{l}\text { Number of Manufacturing Est. } \\
X \text { (larger than } 10 \text { establishments) }\end{array}$ & & $\begin{array}{c}0.679 * * * \\
(0.204)\end{array}$ & & & $\begin{array}{c}0.133 \\
(0.231)\end{array}$ & $\begin{array}{c}0.133 \\
(0.231)\end{array}$ & $\begin{array}{c}0.1 \\
(0.232)\end{array}$ & $\begin{array}{l}0.112 \\
(0.23)\end{array}$ & $\begin{array}{l}0.134 \\
(0.23)\end{array}$ & $\begin{array}{c}0.15 \\
(0.23)\end{array}$ & $\begin{array}{l}0.0828 \\
(0.231)\end{array}$ \\
\hline $\begin{array}{l}\text { Number of Manufacturing } \\
\text { Industries (in logs) }\end{array}$ & & & $\begin{array}{l}0.378^{* *} \\
(0.147)\end{array}$ & $\begin{array}{l}0.285^{*} \\
(0.171)\end{array}$ & $\begin{array}{c}0.29^{*} \\
(0.171)\end{array}$ & $\begin{array}{c}0.29 * \\
(0.171)\end{array}$ & $\begin{array}{c}0.254 \\
(0.172)\end{array}$ & $\begin{array}{c}0.269 \\
(0.171)\end{array}$ & $\begin{array}{c}0.265 \\
(0.171)\end{array}$ & $\begin{array}{c}0.261 \\
(0.171)\end{array}$ & $\begin{array}{c}0.234 \\
(0.172)\end{array}$ \\
\hline $\begin{array}{l}\text { Number of Manufacturing } \\
\text { States (in logs) }\end{array}$ & & & $\begin{array}{c}1.04^{* * *} \\
(0.14)\end{array}$ & $\begin{array}{c}0.908 * * * \\
(0.182)\end{array}$ & $\begin{array}{c}0.883 * * * \\
(0.186)\end{array}$ & $\begin{array}{l}0.882 * * * \\
(0.186)\end{array}$ & $\begin{array}{l}0.925 * * * \\
(0.186)\end{array}$ & $\begin{array}{l}0.872 * * * \\
(0.186)\end{array}$ & $\begin{array}{l}0.868 * * * \\
(0.186)\end{array}$ & $\begin{array}{l}0.872 * * * \\
(0.186)\end{array}$ & $\begin{array}{c}0.912 * * * \\
(0.186)\end{array}$ \\
\hline $\begin{array}{l}\text { Std Dev of Age of Manufacturing } \\
\text { Establishments }\end{array}$ & & & & & & $\begin{array}{c}-0.0131 \\
(0.29)\end{array}$ & & & & & $\begin{array}{l}-0.132 \\
(0.294)\end{array}$ \\
\hline Std Dev of Emp. in Manufacturing & & & & & & & $0.449 * *$ & & & & $0.465^{* *}$ \\
\hline $\begin{array}{l}\text { Establishments } \\
\text { Share of MOPS est. with Ownership }\end{array}$ & & & & & & & $(0.227)$ & 16 & & & $\begin{array}{l}(0.231) \\
1.63 * *\end{array}$ \\
\hline Change in the Prior Year & & & & & & & & $(0.808)$ & & & $(0.804)$ \\
\hline Share of MOPS est. with Ownership & & & & & & & & & $1.07 * *$ & & \\
\hline Change in the Prior 2 Years & & & & & & & & & $(0.532)$ & & \\
\hline Share of MOPS est. with Ownership & & & & & & & & & & $0.75^{*}$ & \\
\hline Change in the Prior 3 Years & & & & & & & & & & $(0.416)$ & \\
\hline Number of Firms & $\sim 3,100$ & $\sim 3,100$ & $\sim 3,100$ & $\sim 3,100$ & $\sim 3,100$ & $\sim 3,100$ & $\sim 3,100$ & $\sim 3,100$ & $\sim 3,100$ & $\sim 3,100$ & $\sim 3,100$ \\
\hline
\end{tabular}

Notes: ***Significant at $1 \%$ level, ${ }^{* *} 5 \%$ level, $* 10 \%$ level. A firm-level regression with the standard deviation of management scores across establishments within the firm as the dependent variable. The regression sample is all firms with $2+$ establishment responses in the MOPS 2010 survey. The total number of establishments, the number of establishments within manufacturing, the number of different industries, the different number of states these establishments span, and the Standard Deviation of age and employment are all calculated from the Longitudinal Business Database (LBD). Change of ownership is defined as share of MOPS establishments with a different FIRMID as compared to a base year's LBD (e.g., LBD 2009 for 09-10). In all columns, we control for a 5 degree polynomial of average management score at the firm. Robust standard errors are reported in parentheses. Establishment sizes and ages are in logs. For scaling purposes all coefficients and standard errors have been multiplied by 100. 
Table 2: Plant Management Scores and Performance

\begin{tabular}{|c|c|c|c|c|c|c|c|c|c|c|}
\hline \multirow[t]{2}{*}{ Dependent Variable } & \multicolumn{4}{|c|}{$\log (\mathrm{VA} / \mathbf{E m p})$} & \multicolumn{2}{|c|}{$\begin{array}{c}\text { Emp. Growth } \\
2010-2013\end{array}$} & \multicolumn{2}{|c|}{$\begin{array}{c}\text { Exit } \\
2010 \text { to } 2013\end{array}$} & \multirow{2}{*}{$\begin{array}{c}\text { Profit/Sales } \\
(9)\end{array}$} & \multirow{2}{*}{$\begin{array}{c}\mathbf{R} \& \mathbf{D} / \\
\mathbf{E m p} \\
(10)\end{array}$} \\
\hline & $(1)$ & $(2)$ & (3) & (4) & $(5)$ & $(6)$ & $(7)$ & $(8)$ & & \\
\hline Management & $\begin{array}{l}1.272 * * * \\
(0.05)\end{array}$ & $\begin{array}{c}0.498 * * * \\
(0.037)\end{array}$ & $\begin{array}{c}0.298 * * * \\
(0.065)\end{array}$ & $\begin{array}{c}0.233 * * * \\
(0.082)\end{array}$ & $\begin{array}{l}0.056 * * * \\
0.005\end{array}$ & $\begin{array}{c}0.052 * * * \\
0.005\end{array}$ & $\begin{array}{c}-0.019 * * * \\
0.002\end{array}$ & $\begin{array}{c}-0.018 * * * \\
0.002\end{array}$ & $\begin{array}{l}0.058 * * * \\
(0.01)\end{array}$ & $\begin{array}{c}0.385 * * * \\
(0.104)\end{array}$ \\
\hline $\log ($ Capital/Emp) & & $\begin{array}{c}0.179 * * * \\
(0.007)\end{array}$ & $\begin{array}{l}0.036^{*} \\
(0.02)\end{array}$ & $\begin{array}{c}0.193 * * * \\
(0.016)\end{array}$ & & & & & $\begin{array}{l}0.01 * * * \\
(0.002)\end{array}$ & $\begin{array}{l}0.12 * * * \\
(0.016)\end{array}$ \\
\hline $\log (\operatorname{Emp})$ & & $\begin{array}{c}-0.035 * * * \\
(0.006)\end{array}$ & $\begin{array}{c}-0.198 * * * \\
(0.029)\end{array}$ & $\begin{array}{c}-0.064 * * * \\
(0.012)\end{array}$ & & & & & $\begin{array}{c}0.001 \\
(0.002)\end{array}$ & $\begin{array}{c}0.102 * * * \\
(0.014)\end{array}$ \\
\hline $\begin{array}{l}\text { Share employees } w \text {. } \\
\text { a college degree }\end{array}$ & & $\begin{array}{c}0.418 * * * \\
(0.041)\end{array}$ & $\begin{array}{l}-0.096 \\
(0.138)\end{array}$ & $\begin{array}{c}0.421 * * * \\
(0.076)\end{array}$ & & & & & $\begin{array}{c}0.004 \\
(0.011)\end{array}$ & $\begin{array}{c}1.008 * * * \\
(0.09)\end{array}$ \\
\hline Productivity (TFP) & & & & & & $\begin{array}{l}0.033 * * * \\
0.005\end{array}$ & & $\begin{array}{c}-0.009 * * * \\
0.002\end{array}$ & & \\
\hline Observations & 31,793 & 31,793 & 35,688 & 17,235 & 31,793 & 31,793 & 31,793 & 31,793 & 31,793 & 13,888 \\
\hline Num. establishments & 31,793 & 31,793 & 17,844 & 17,235 & 31,793 & 31,793 & 31,793 & 31,793 & 17,843 & 4,914 \\
\hline Num. firms (clusters) & 17,843 & 17,843 & 10,557 & 3,285 & 17,843 & 17,843 & 17,843 & 17,843 & 17,843 & 4,914 \\
\hline Fixed Effects & None & Industry & Establish. & Firm & Industry & Industry & Industry & Industry & Industry & Industry \\
\hline
\end{tabular}

Notes: $* * *$ Significant at $1 \%$ level, $* * 5 \%$ level, $* 10 \%$ level. OLS coefficients with standard errors in parentheses (clustered at the firm level). The management score is the unweighted average of the score for each of the 16 questions, where each question is first normalized to be on a $0-1$ scale. The sample in all columns is all MOPS observations with at least 11 non-missing responses to management questions and a successful match to ASM, which were also included in ASM tabulations, have positive value added, positive employment and positive imputed capital in the ASM. In columns (1) through (4) the dependent variable is $\log$ (real value added over total employment). In columns (5) to (6) the dependent variable is employment growth between 2010 and 2013. Growth is calculated as $0.5 *\left(\mathrm{e}_{2013}-\mathrm{e}_{2010}\right) /\left(\mathrm{e}_{2013}+\mathrm{e}_{2010}\right)$. In columns (7) to (8) the dependent variable is a dummy that takes the value of 1 for exit between 2010 and 2013. In columns (5)-(8), both TFP and management are normalized by their standard deviation for easier comparison of their association with growth and exit. In column (9) profits are measured by value added minus wages and salaries over total value of shipments. Dependent variable in column (10) is $\log (1+(\mathrm{R} \& \mathrm{D}$ per 1000 employees $))$ from BRDIS. When we include establishment fixed effects, we pool the years 2005 and 2010, with a dummy for 2010. Noise controls include: the absolute difference in reported employment in the ASM and MOPS; a dummy for whether filing was online (zero if by mail); filing date; day of week; respondent tenure and seniority. 
Table 3: Drivers of TFP Variation

(1)

Dependent Variable:

(2)

Revenue-based Total Factor Productivity

Management score

$0.684 * * *$

$(0.040)$

$\mathrm{R} \& \mathrm{D}$

IT/worker

$0.098 * * *$

(0.009)

Skills (\% employees

with college degree)
(4)

(5)

(3)

\begin{tabular}{|c|c|c|c|c|c|}
\hline Observations & 17,843 & 17,843 & 17,843 & 17,843 & 17,843 \\
\hline Share of 90-10 explained & 0.181 & 0.169 & 0.0752 & 0.111 & 0.325 \\
\hline
\end{tabular}

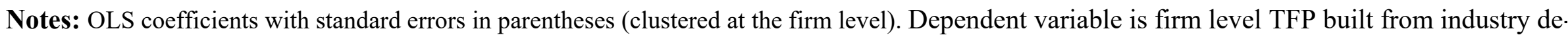

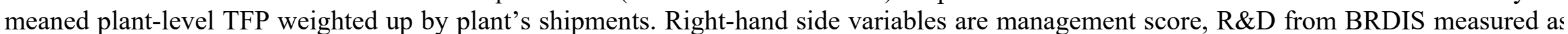

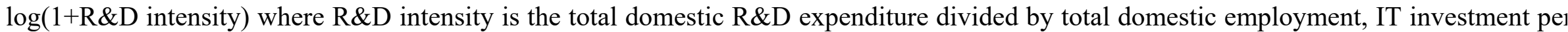

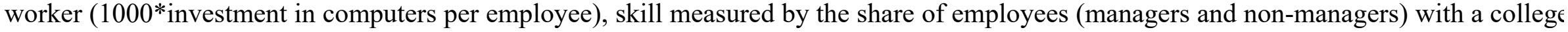

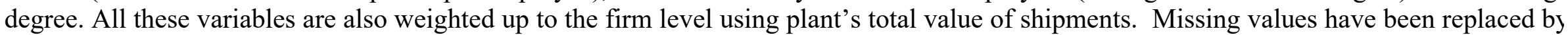

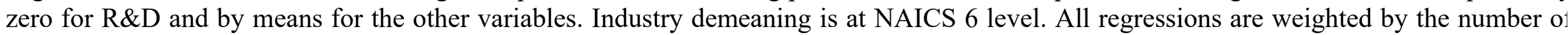

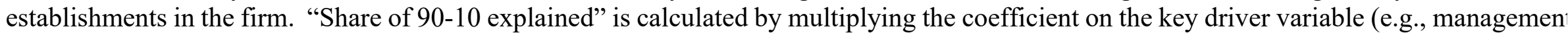
in column 1) by its 90-10 spread and dividing this by the 90-10 spread of TFP. 
Table 4: Product Market Competition and Management

\begin{tabular}{|c|c|c|c|c|c|c|c|c|c|}
\hline \multirow{2}{*}{ Dependent Variable: } & (1) & (2) & (3) & (4) & (5) & (6) & (7) & (8) & (9) \\
\hline & \multicolumn{3}{|c|}{ Management } & \multicolumn{6}{|c|}{ Change in Management } \\
\hline 1-Lerner & $\begin{array}{c}0.134 * * * \\
(0.043)\end{array}$ & $\begin{array}{l}0.053 * * \\
(0.023)\end{array}$ & $\begin{array}{c}0.014 \\
(0.024)\end{array}$ & & & & & & \\
\hline Change in (1-Lerner) & & & & $\begin{array}{l}0.024 * * \\
(0.011)\end{array}$ & $\begin{array}{c}0.030 * * \\
(0.012)\end{array}$ & $\begin{array}{c}0.035^{* *} \\
(0.018)\end{array}$ & & & \\
\hline $\begin{array}{l}\text { Change in Industry } \\
\text { Exchange Rate }\end{array}$ & & & & & & & $\begin{array}{c}0.102 * * * \\
(0.036)\end{array}$ & $\begin{array}{c}0.097 * * * \\
(0.029)\end{array}$ & $\begin{array}{l}0.111 * * \\
(0.053)\end{array}$ \\
\hline Full controls & & Yes & Yes & & Yes & Yes & & Yes & Yes \\
\hline Naics3 FE & & Yes & Yes & & Yes & Yes & & Yes & Yes \\
\hline Firm FE & & & Yes & & & Yes & & & Yes \\
\hline Sample & Baseline & Baseline & Baseline & Panel & Panel & Panel & Panel & Panel & Panel \\
\hline Observations & 31,793 & 31,793 & 31,793 & 17,844 & 17,844 & 17,844 & 17,844 & 17,844 & 17,844 \\
\hline
\end{tabular}

Notes: The sample in columns (1) to (3) is our baseline sample, and in columns (4) to (9) the panel sample of establishments that have management data for both 2005 and 2010. The right-hand variable is the level of the Lerner index of competition in 2007 columns (1)-(3), and in columns (4) to (6) the change in the Lerner Index from 2002-2007. In columns (7)-(9) the dependent variable is the change in the 4-digit industry measure of exchange rates weighted up using initial period industry trade-shares (noting high values mean a strong dollar, so more competition). Full controls include ASM size (log employment), log capital stock, share of employees with a degree, responder tenure, with values for all controls in 2010 for levels results and in 2005 and 2010 for difference results. Standard errors are clustered at the NAICS 6-digit industry level.

Table 5: Product Market Competition and Quantiles of the Management Score

\begin{tabular}{|c|c|c|c|c|c|c|}
\hline \multicolumn{7}{|l|}{ Dependent Variable: } \\
\hline Management Score & (1) & (2) & (3) & (4) & (5) & (6) \\
\hline Quantile & All & $10^{\text {th }}$ & $25^{\text {th }}$ & $50^{\text {th }}$ & $75^{\text {th }}$ & $90^{\text {th }}$ \\
\hline Lerner index & $\begin{array}{c}0.134 * * * \\
(0.043)\end{array}$ & $\begin{array}{c}0.259 * * * \\
(0.084)\end{array}$ & $\begin{array}{c}0.197 * * * \\
(0.066)\end{array}$ & $\begin{array}{c}0.145^{* * *} \\
(0.046)\end{array}$ & $\begin{array}{c}0.087 * * * \\
(0.032)\end{array}$ & $\begin{array}{c}0.053 * * * \\
(0.019)\end{array}$ \\
\hline Observations & 31,793 & 31,793 & 31,793 & 31,793 & 31,793 & 31,793 \\
\hline
\end{tabular}

Notes: Quantile regressions of management score on a competition measure. The sample is our baseline sample. The independent variable is the Lerner measure of competition. Column (1) is replicating column (1) from Table 4. Columns (2)-(6) correspond to a different quantile regression with the relevant quantile listed at the top of each column. Standard errors are blocked bootstrapped at the industry level. 
Table 6: Management and the Business Environment

\begin{tabular}{|c|c|c|c|c|c|c|}
\hline \multirow[t]{2}{*}{ Dependent Variable } & \multicolumn{4}{|c|}{ Management Score } & \multirow{2}{*}{$\begin{array}{c}\text { Promotions and } \\
\text { Dismissals }\end{array}$} & \multirow{2}{*}{$\begin{array}{c}\begin{array}{c}\text { All but } \\
\text { Promotions and } \\
\text { Dismissals }\end{array} \\
(6) \\
\end{array}$} \\
\hline & $(1)$ & (2) & (3) & (4) & & \\
\hline RTW state & $\begin{array}{c}0.014 * * \\
(0.006)\end{array}$ & $\begin{array}{c}0.022 * * * \\
(0.008)\end{array}$ & & & $\begin{array}{c}0.031 * * * \\
(0.007)\end{array}$ & $\begin{array}{c}0.008 \\
(0.006)\end{array}$ \\
\hline Oldest in RTW state & & & $\begin{array}{c}0.027 * * * \\
(0.002)\end{array}$ & & & \\
\hline HQ in RTW state & & & & $\begin{array}{c}0.015 * * * \\
(0.003)\end{array}$ & & \\
\hline Establishments: & 5,143 & 2,929 & 16,280 & 16,280 & 5,143 & 5,143 \\
\hline Distance from border: & $<=50 \mathrm{~km}$ & $<=50 \mathrm{~km}$ & All & All & $<=50 \mathrm{~km}$ & $<=50 \mathrm{~km}$ \\
\hline Sample & All & $\begin{array}{c}\text { Non- } \\
\text { Tradable }\end{array}$ & Multi-Unit & Multi-Unit & All & All \\
\hline Border FE & Yes & Yes & $\mathrm{n} / \mathrm{a}$ & $\mathrm{n} / \mathrm{a}$ & Yes & Yes \\
\hline State FE & $\mathrm{n} / \mathrm{a}$ & $\mathrm{n} / \mathrm{a}$ & Yes & Yes & $\mathrm{n} / \mathrm{a}$ & $\mathrm{n} / \mathrm{a}$ \\
\hline
\end{tabular}

Note: Observations in columns (1), (2), (5) and (6) are establishment-border combinations across "Right To Work" (RTW) and NonRTW (NRTW) borders. Non-Tradables are the 118 industry categories (out of 472) with the lowest regional concentration level calculated following Ellison and Glaeser (1997) using data from the 2007 census. Columns (3) and (4) sample includes all establishment in multi-unit firms with at least one establishment in a RTW and one-establishment in a NRTW state. We consider a firm to have a RTW headquarter if it has at least one establishment in the Longitudinal Business Database (LBD) with NAICS code 551114 "corporate, subsidiary and regional managing offices" located in a RTW state. If no establishment in the firm has this NAICS code, we instead define the headquarters as the oldest establishment in the firm. Standard errors in columns (1) and (2) are calculated using the establishment-border data and are clustered at the border level, while standard errors in columns (3) and (4) are clustered at the firm level. All specifications include industry fixed-effects. 
Table 7: Management Knowledge Spillovers

\begin{tabular}{|c|c|c|c|c|c|c|}
\hline \multirow[t]{2}{*}{ Dependent variable: } & \multicolumn{2}{|c|}{$\begin{array}{c}\text { Change in } \\
\text { Management }\end{array}$} & \multicolumn{2}{|c|}{ Change in TFP } & \multicolumn{2}{|c|}{ Change in Log(employment) } \\
\hline & $(1)$ & $(2)$ & (3) & (4) & $(5)$ & $(6)$ \\
\hline \multicolumn{7}{|l|}{ Panel A: All Industries Pooled } \\
\hline Million Dollar Plant Opens & $\begin{array}{c}0.017 * * * \\
(0.006)\end{array}$ & $\begin{array}{c}0.013 * * \\
(0.005)\end{array}$ & $\begin{array}{c}0.032 \\
(0.050)\end{array}$ & $\begin{array}{c}0.026 \\
(0.050)\end{array}$ & $\begin{array}{c}0.124 * * * \\
(0.020)\end{array}$ & $\begin{array}{c}0.126 * * * \\
(0.018)\end{array}$ \\
\hline \multicolumn{7}{|l|}{ Panel B: Manufacturing MDPs Split Out } \\
\hline Million Dollar Plant Opens $\times$ (Manufacturing) & $\begin{array}{c}0.021 * * * \\
(0.003)\end{array}$ & $\begin{array}{c}0.016 * * * \\
(0.003)\end{array}$ & $\begin{array}{c}0.110 * * * \\
(0.026)\end{array}$ & $\begin{array}{c}0.106 * * * \\
(0.026)\end{array}$ & $\begin{array}{c}0.159 * * * \\
(0.014)\end{array}$ & $\begin{array}{c}0.157 * * * \\
(0.017)\end{array}$ \\
\hline Million Dollar Plant Opens $\times$ (Non-Manufacturing) & $\begin{array}{c}0.008 \\
(0.014) \\
\end{array}$ & $\begin{array}{c}0.003 \\
(0.013) \\
\end{array}$ & $\begin{array}{c}-0.175^{* * *} * \\
(0.059)\end{array}$ & $\begin{array}{c}-0.184 * * * \\
(0.06)\end{array}$ & $\begin{array}{c}0.034 \\
(0.051)\end{array}$ & $\begin{array}{l}0.045 \\
(0.05) \\
\end{array}$ \\
\hline Full Controls: & No & Yes & No & Yes & No & Yes \\
\hline Observations & 1,152 & 1,152 & 1,152 & 1,152 & 1,152 & 1,152 \\
\hline
\end{tabular}

Notes: The sample in all columns is our baseline sample (all MOPS observations with at least 11 non-missing responses to management questions with a successful match to ASM, which were also included in ASM tabulations, have positive value added, positive employment and positive imputed capital in the ASM) restricted to plants in counties that were considered by "Million Dollar Plants" (MDPs) as part of the site selection process between 2005 and 2010 (inclusive). The dependent variable is the change from 2005 to 2010 in - for columns (1)-(2): change in management score winsorized at top and bottom 1\%, columns (3) and (4) $\log$ (TFP), columns (5) and (6) change in $\log ($ employment). The key right-hand side variable is a dummy indicating whether the plant was in the county finally selected for the plant location or not. All regressions have pair fixed effects and standard errors are clustered at the pair level. Full controls include establishment age, age squared, share of employees with a degree, and share of employees in a union. The top and bottom panels report results of different regressions. 
Table 8: Management and Education

\begin{tabular}{|c|c|c|c|c|}
\hline \multicolumn{5}{|c|}{ Dependent Variable: Management Score } \\
\hline & (1) & (2) & (3) & (4) \\
\hline Specification & OLS & OLS & OLS & IV \\
\hline \multirow[t]{2}{*}{ Land Grant in $\mathrm{MSA}^{\wedge}$} & $0.528 * *$ & $0.418^{*}$ & & \\
\hline & $(0.211)$ & $(0.254)$ & & \\
\hline \multirow[t]{2}{*}{ Share in county with $\mathrm{BA}+$} & & & $0.037 * * *$ & $0.133 * *$ \\
\hline & & & $(0.012)$ & $(0.054)$ \\
\hline \multicolumn{2}{|l|}{$1^{\text {st }}$ stage F-stat } & & & 31.42 \\
\hline Firm FE & No & Yes & No & No \\
\hline Observations & 31,793 & 17,235 & 31,793 & 31,793 \\
\hline
\end{tabular}

Notes: Regressions of the combined management score on measures of local skill levels. Columns (1)-(3) are OLS regressions while in column (4) we instrument Share in county with BA or above with the presence of a Land Grant College (LGC). All columns have area level controls for population density and the unemployment rate as well as industry and state fixed effects. Establishment-level controls include $\log ($ employment), $\log ($ age $)$, multi-unit dummy, exporter dummy, and union share. High skill and low skill industries are above and below median industries using the degree variable in our sample. Coefficient and standard error on Land Grand Colleges multiplied by 100. Standard errors clustered at the MSA.

\section{Table 9: Quantification of Management Drivers}

\begin{tabular}{lcccc}
\hline \hline & Driver 90-10 & Coefficient & Implied 90-10 & Implied share of true management 90-10 \\
\hline Competition & 0.25 & 0.053 & 0.013 & $6.3 \%$ \\
Business Regulation & 1 & 0.022 & 0.022 & $10.5 \%$ \\
Spillovers (Million Dollar Plants) & 1 & 0.013 & 0.013 & $6.2 \%$ \\
Education & 0.25 & 0.133 & 0.033 & $15.7 \%$ \\
Total & & & & $\mathbf{3 8 . 7} \%$ \\
\hline \hline
\end{tabular}

Notes: "Driver 90-10" is the 90-10 spread of the variable in the data (for competition and education - this comes from estimates from Compustat and the ACS since we cannot clear out sample values). "Coefficient"” is our regression coefficient from our preferred regression result for that driver - which for competition, business regulation, spillovers and education is column (2) Table 4, column (3) Table 6, column (2) Table 7, and column (6) Table 8, respectively. The "Implied 90-10" is column (1) multiplied by column (2). Finally, "Implied share of true management 90-10" is the implied 90-10 from column (3) as a percentage of 0.210, which is our calculated true management $90-10$. This value of 0.210 comes from the measured management $90-10$ (which is 0.385 , as shown in Table A2) multiplied by the 0.546 (the share of this variation that is real rather than measurement error, as discussed in Section 3). 


\section{Figure 1: The Wide Spread of Management Scores Across Establishments}

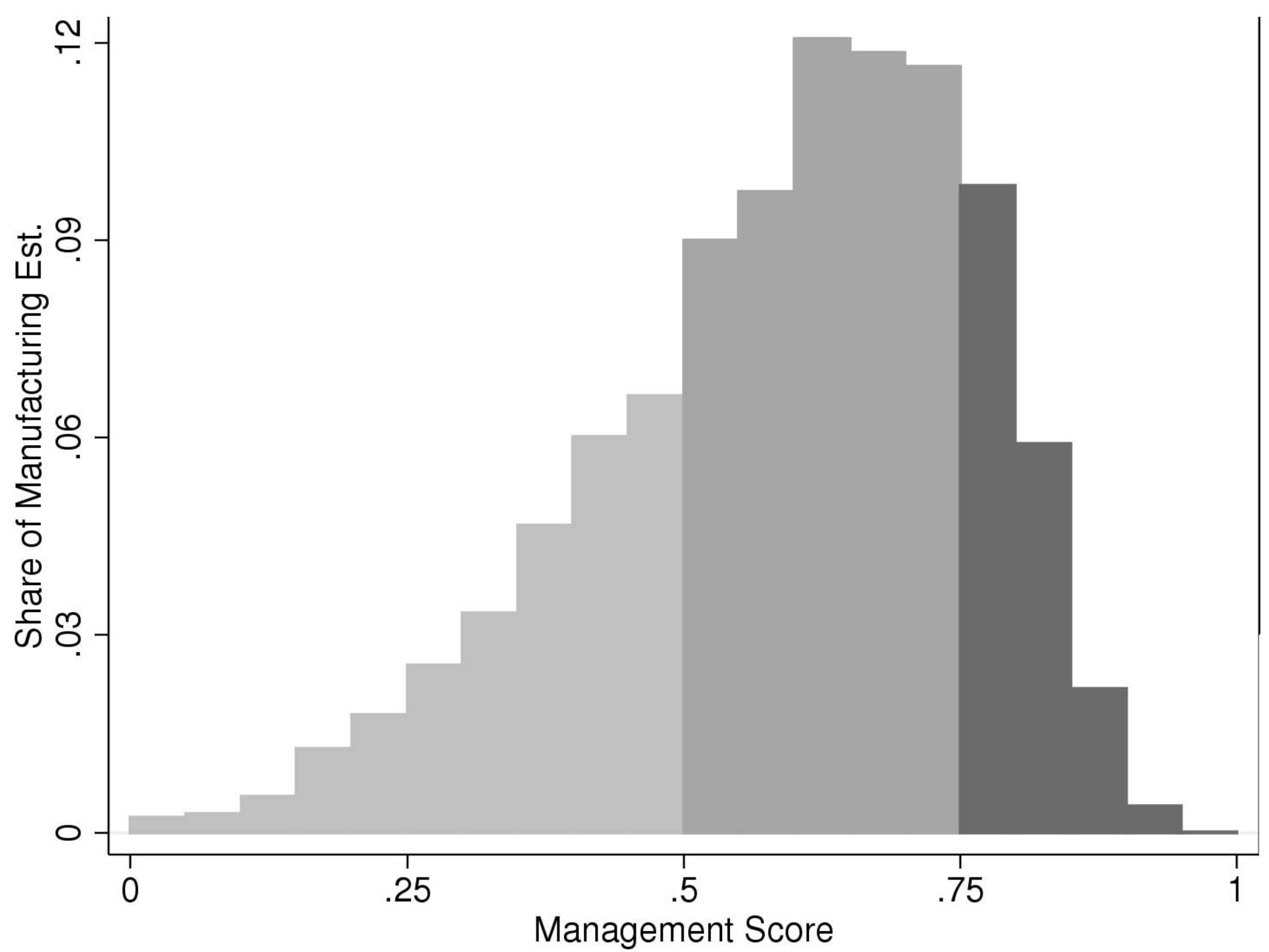

Note: The management score is the unweighted average of the score for each of the 16 questions, where each question is first normalized to be on a 0-1 scale. The sample is all MOPS observations with at least 11 non-missing responses to management questions and a successful match to ASM, which were also included in ASM tabulations, and have positive value added, positive employment and positive imputed capital in the ASM. Figures are weighted using ASM weights. 
Figure 2: The firm-level share of the variation in management scores (after removing measurement error)

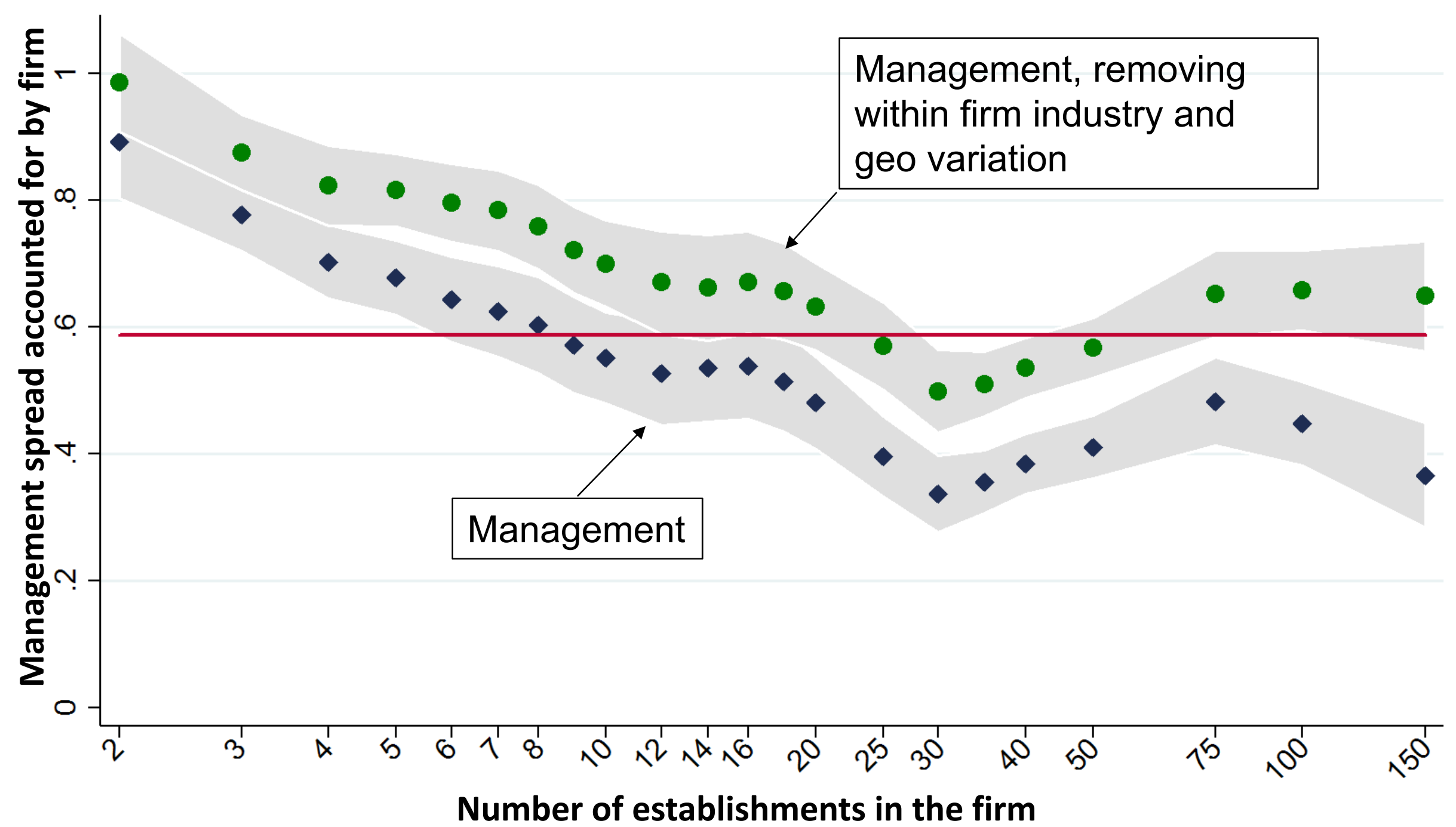

Note: Dots show the share of management score variation accounted for by the firm with different numbers of manufacturing establishments ranging from that number to the next value - so for example, 50 plants refers to 50 to 74 plants. After removing the $45.4 \%$ accounted for by measurement error. The bootstrap sampled $95 \%$ confidence interview shown in grey shading. Sample of 16,500 establishments across the 3100 firms with 2+ establishments in the 2010 MOPS survey. 
Figure 3: The distribution of the management regression coefficient over 86 NAICS four-digit industries

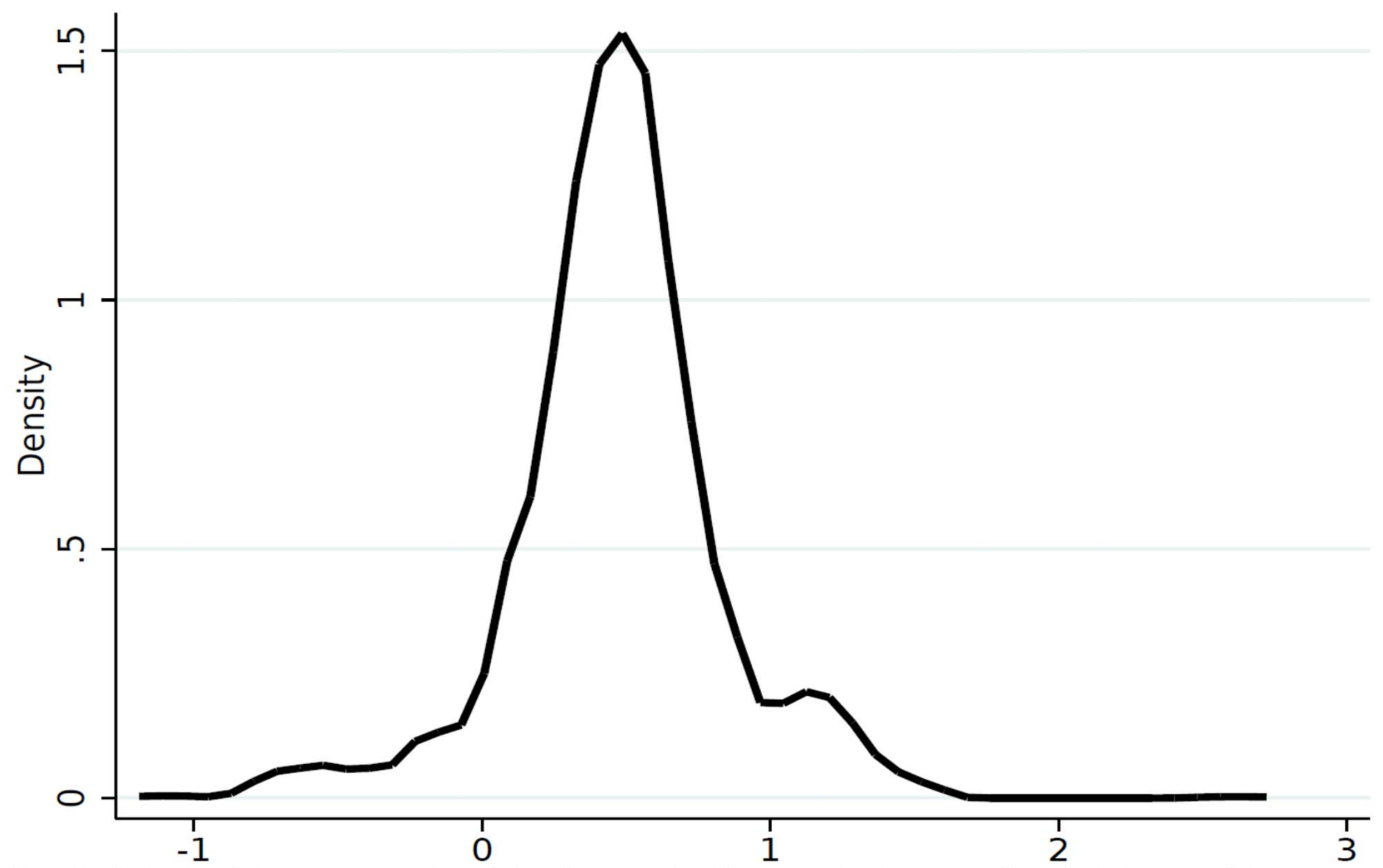

Note: Smoothed density of the management coefticient from running the regression in column (2) of Table 2 separately for each of the 86 four-digit manufacturing NAICS codes. The sample of 31,793 is all MOPS observations with at least 11 non-missing responses to management questions and a successful match to ASM, which were also included in ASM tabulations, have positive value added, positive employment and positive imputed capital in the ASM. 


\section{Figure 4: Performance and Structured Management}
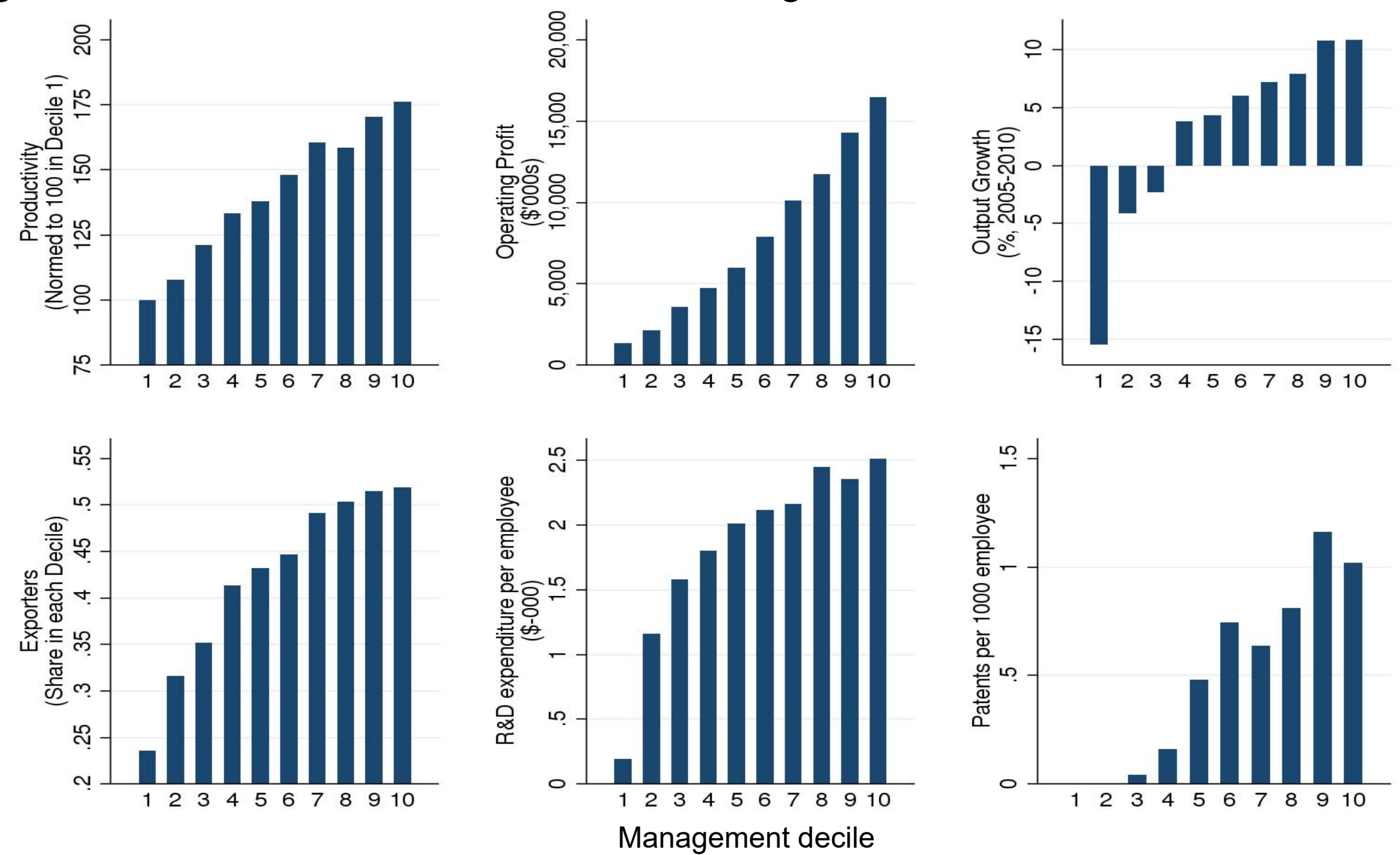

Note: The management score is the unweighted average of the score for each of the 16 questions, where each question is first normalized to be on a 0-1 scale. The sample for panels 1, 2 and 4 is all MOPS observations with at least 11 non-missing responses to management questions and a successful match to ASM, which were also included in ASM tabulations, and have positive value added, positive employment and positive imputed capital in the ASM. The sample in panel 3 is similar to panel 1, but also conditions on nonmissing total value in the ASM 2005. The sample for panels 5 and 6 is similar to panel 1 , also conditioning on non-missing R\&D or patents requests count in the BRDIS survey. Management deciles are calculated using 2010 management scores for all panels. The deciles are re-calculated for the different samples. The figures are unweighted. 


\section{For Online Publication}

\section{Appendix A: Data}

Sample Selection: The sample for the 2010 MOPS consisted of the approximately 50,000 establishments in the 2010 Annual Survey of Manufacturers (ASM) mailout sample. The mailout sample for the ASM is redesigned at 5-year intervals beginning the second survey year subsequent to the Economic Census. (The Economic Census is conducted every five years in years ending in '2' or ' 7 .') For the 2009 survey year, a new probability sample was selected from a frame of approximately 117,000 manufacturing establishments of multi-location companies and large singleestablishment companies in the 2007 Economic Census, which surveys establishments with paid employees located in the United States. Using the Census Bureau's Business Register, the mailout sample was supplemented annually by new establishments, which have paid employees, are located in the United States, and entered business in 2008 2010.1

Overall, 49,782 MOPS surveys were sent, of which 2,248 were undeliverable as addressed. For the 47,534 surveys which were successfully delivered, 37,177 responses were received, implying a high response rate of $78 \%$. For most of our analysis, we further restrict the sample to establishments with at least 11 non-missing responses to management questions (including those that missed questions by correctly following the skip pattern) and a successful match to ASM, which were also included in ASM tabulations, have a valid identifier in the LBD (LBDNUM), have positive value added, positive employment and positive imputed capital in the ASM (see below for details on capital imputation). Table A3 shows how the numbers of firms and average employment changes as we condition on different sub-samples.

In Table A1, we report the results for linear probability models for the different steps in the sampling process. In column (1) the sample is 2010 ASM observations with positive employment and sales and the dependent variable is an indicator that equals 1 if MOPS was sent to the establishment and zero otherwise. The right hand side of the regression includes the log of employment and a set of region and industry dummies. The establishments that were mailed the MOPS survey are somewhat larger. This difference between the ASM respondents and the MOPS mail sample is in part due to the continued sampling of new births in the ASM throughout the survey year, which focuses particularly on gathering data for large establishments. However, because the MOPS was mailed after the ASM, some ASM cases did not receive the MOPS due to status updates. In column (2), we compare MOPS respondents to the MOPS mail-out sample, finding that MOPS respondents tend to be slightly larger. Finally, in columns (3) to (5), we compare our "clean" sample to the sample of respondents and to the ASM sample, finding again that the "clean" sample has slightly larger establishments, which are also slightly more productive (column (5)).

Management Scores: The management score for each establishment is generated in two steps.2 First, the responses to each of the 16 management questions are normalized on a $0-1$ scale. The response which is associated with the most structured management practice is normalized to 1 , and the one associated with the least structured is normalized to zero. We define more structured management practices as those that are more specific, formal, frequent or explicit. For example, when asking "... when was an under-performing non-manager reassigned or dismissed?", the response "Within 6 months of identifying non-manager under-performance" is ranked 1 and the response "Rarely or never" is ranked 0. If a question has three categories, the "in between" category is assigned the value 0.5. Similarly for four categories the "in between" categories are assigned 1/3 and 2/3 and so on. 3 Second, the management score is calculated as the unweighted average of the normalized responses for the 16 management questions. In robustness tests, we also

1 This paragraph is from the official methodological documentation for the 2010 MOPS, which can be found at https://www.census.gov/mcd/mops/how the data are_collected/index.html. The certainty category slightly differs over industries. For more details on the ASM sample design see: http://www.census.gov/programssurveys/asm/technical-documentation/methodology.html

2 The full survey instrument is available on http://www.census.gov $/ \mathrm{mcd} / \mathrm{mops} / \mathrm{how}$ the_data_are_collected/MP10002_16NOV10.pdf

3 For multiple choice questions which allow for the selection of more than one answer per year, we use the average of the normalized answers as the score for the particular question. If the question does not allow for the selection of more than one answer, but more than one box is selected, we treat the observation as missing. 
evaluated another way to average across the 16 individual scores. We used a management z-score, which normalizes each question to have a mean of 0 and a standard deviation of 1 and averaging across these. We found that all our results were extremely similar because the average z-score is extremely correlated with our main management measure.

\section{Share of employees with a degree:}

To generate our firm level measure of employees with a degree we used the mid-point values in the bin responses in questions 34 and 35 scaled up by the share of managers and non-managers in the firm calculated from the response to questions 32 and 33.

\section{Additional Databases:}

Establishment level: Our primary source of establishment-level external data is the ASM from 2003 to 2010 . We use the CM from 2002 and 2007 to obtain data on capital stocks, which is then combined with the ASM data on investment flows to impute capital stock for 2005 and 2010 (see details below). The CM has been conducted every 5 years (for years ending 2 and 7) since 1967. It covers all establishments with one or more paid employees in the manufacturing sector (SIC 20-39 or NAICS 31-33) which amounts to 300,000 to 400,000 establishments per survey. Both the CM and the ASM provide detailed data on sales/shipments, value added, labor inputs, labor cost, cost of materials, capital expenditures, inventories and much more. We match the MOPS to the ASM using the SURVU_ID variable, and match the ASM to the CM, as well as ASM and CM over time using the LBDNUM variable. Finally, we use the Longitudinal Business Database (LBD) to describe the universe of establishments in Table A3 as well as for the calculation of firm level characteristics such as age, spread of age and employment, and number of industries and locations the firm operates in.

Firm level: We use the 2009 Business R\&D and Innovation Survey (BRDIS) data to obtain information on R\&D spending and patent applications by the parent firm associated with each establishment. BRDIS provides a nationally representative sample of all companies with 5 or more employees. It is conducted jointly by the Census Bureau and the NSF and collects data on a variety of R\&D activities. It replaced the Survey of Industrial Research and Development (SIRD) in 2008. The BRDIS is matched to the ASM (and then to MOPS) using the LBD. We are able to match a total of 13,888 MOPS observations in our "clean" sample to BRDIS observations with non-missing data on R\&D spending and patent applications.4

Industry level: We use the NBER-CES data for industry-level price indices for total value of shipments (PISHIP), and capital expenditures (PIINV), as well as for total cost of inputs for labor (PAY), used in the construction of cost share. We match the NBER data to the establishment data using 6-digit NAICS codes.5 We use the BLS multifactor productivity database for constructing industry-level cost of capital and capital depreciation, and the BEA fixed assets tables to transform establishment-level capital book value to market value.6

Competition: We use cross-sectional as well as changes in the industry competition measures to study the effect of competition on management. For import penetration, we use publically available trade data by detailed NAICS codes complied by the U.S. Census.7 We calculate the Lerner indexes using the CM. Finally, for exchange rate shocks, we follow Bertrand (2004) and Bloom et al. (2016) in using changes in exchange rates to generate exogenous variation in trade competition. We use three additional data sets in the construction of these exchange rate shocks. The IMF IFS

4 For more details see http:/www.census.gov/manufacturing/brdis/index.html and http://www.nsf.gov/statistics/srvyindustry/about/brdis/interpret.cfm.

5 See: http://www.nber.org/data/nbprod2005.html for the public version. We thank Wayne Gray for sharing his version of the dataset that is updated to 2009. Since The NBER-CES data are available only up to 2009, we use the 2009 values for 2010 for all external data. There are 2 industries $(327111,327112)$ that are missing MATCOST for 2008, and two $(331411,331419)$ that are missing it starting 2006. These observations are therefore missing cost shares for (which are used to calculate TFP). For these 4 industries we roll forward the last value for which we have cost shares.

6 For more details about the relevant variables from the BLS and BEA tables, see the appendix to Bloom, Floetotto, Jaimovich, Terry and Saporta (2012).

7 http://sasweb.ssd.census.gov/relatedparty/ 
website is used for downloading exchange rates between local currencies of 15 countries and the U.S. dollar. We then obtain price deflators for the 15 countries from the OECD website. We use data from Peter K. Schott's website for exports and imports share by country to generate industry-weighted exchange rates.

Multinationals: We use Site Selection to find "Million Dollar Plants" as described by Greenstone, Hornbeck and Moretti (2008). However, the original feature in Site Selection that lists impactful plant openings stopped in 1997, so we recreate the list based on articles about plant openings and key terms for which to search.8 The key terms used include "blockbuster deal archive," "runner up," "winning bid," "top deals" and "location report." To include an establishment in the Million Dollar Plants list, we require the following criteria - the winner and runner-up locations announced, at least one runner-up location in the U.S., and plant started between 2005 and 2010.

Capital Imputation: As mentioned above, the capital measures are based on the CM 2002 and 2007 reported book value of assets. We first transform book values to market using the industry-level BEA fixed assets tables, and then deflate both the initial stock and the investment flows using the NBER deflators. We then apply the perpetual inventory method (PIM) to impute capital stocks for 2005 and 2010. This procedure only provides us with capital stock values in 2010 for establishments which were in the CM in 2007 and in the ASM in both 2008, 2009 and in the ASM 2010 but do not follow this criteria:

(a) If investment in 2009 is missing, impute it using the average investment for the plant in 2008 and 2010 (or 2007 and 2010 if 2008 missing).

(b) Similarly, if investment in 2008 is missing, impute it using 2007 and 2009 (or 2007 and 2010 if 2009 is missing).

(c) For 2008 and 2009 births, use the establishment's 2008 or 2009 investment to initialize the capital stock. To do that use the 2007 median ratio of book value to investment for new establishments by 6 digit NAICS (winsorized at the $95 \%$, since some industries have very small number of observations). Run the PIM again using these initial capital stocks, only for observations with missing capital stock in 2010.

(d)

For observations that are still missing capital stock, impute it by using the industry median ratio of book value of capital stock to investment (these are establishments which appear in 2008 or 2009 but not in 2007, but are not marked as births). Run the PIM again only on the establishments with missing capital stock in 2010.

(e) Finally, if PIM implied zero capital stock for 2010, but investment in 2010 is positive, impute the 2010 stock using industry median as in (d).

Performance measures: Below is a summary of the measures used in the analysis:

Value added per worker: Calculated as establishment value added over total employment. In Figure 4 raw (nominal) value added is used, while in Table 2 it is deflated using industry level deflators.

Value added TFP: Value-added TFP is calculated using cost shares following for example Foster, Haltiwanger, and Krizan (2001).9 Our log TFP measure is defined as

$$
\log F P_{i}=\log Y_{i}-\alpha \log K_{i}-\beta \log L_{i},
$$

where $Y_{i}$ is real value added, $K_{i}$ is capital input recovered as described in the capital imputation paragraph above. $L_{i}$ is labor input calculated as

$$
L_{i}=\frac{\text { total salaries }}{\text { production worker salaries }} * \text { production hours }
$$

Finally, to recover $\alpha$ and $\beta$ we use cost share at the industry 6-digit NAICS industry level. The total cost of labor inputs for industry $j\left(c_{j}^{L}\right)$ is taken from the NBER-CES Manufacturing Industry Database (PAY). The cost of capital $\left(c_{j}^{K}\right)$ is set to be capital income at the industry level. The BLS productivity dataset includes data on capital income at the 3-digit NAICS level. To obtain capital income at 6-digit level we apply the ratio of capital income to capital input calculated using BLS data to the 6-digit NBER-CES real capital stock measure. Once the two input costs are recovered at the industry level, the cost share is simply recovered as

8 We are grateful to Hyunseob Kim for sharing an updated list of million dollar plants and discussing search strategies from his work Kim (2013)

9 The main difference is that we use a single capital stock, rather than separating equipment and structures, because separate stocks are no longer reported in the $\mathrm{CM}$ in recent years. 


$$
s_{j}^{L}=\frac{c_{j}^{L}}{c_{j}^{L}+c_{j}^{K}}, s_{j}^{K}=\frac{c_{j}^{K}}{c_{j}^{L}+c_{j}^{K}}
$$

and $\log (\mathrm{TFP})$ at the establishment level is measured as

$$
\log \widehat{\left(T F P_{l, j}\right)}=\log Y_{i}-s_{j}^{K} \log K_{i}-s_{j}^{L} \log L_{i}
$$

(for further detail about local input prices, see Appendix B).

Employment Growth: We define growth of employment from 2005 to 2010 as $\left(\mathrm{emp}_{2010}\right.$-emp 2005$) /$ $\left(0.5 * \mathrm{emp}_{201}+0.5 * \mathrm{emp}_{2005)}\right.$.

Profitability: We measure profitability from ASM data as [value added-total salaries]. In Figure 4 we use this value for profitability, while in the regressions in Table 2 we use (value added- total salaries)/(total value of shipments).

$\underline{R} \& D$ intensity: $R \& D$ intensity is defined as (domestic $R \& D$ expenditures)/(domestic employees). In the regressions in Table 2 , the dependent variable is $\log (1+R \& D$ intensity $)$.

Patent intensity: R\&D intensity is defined as (patent applications)/(domestic employment). In Figure 4 we report this measure multiplied by a 1,000 . In the footnote to the text discussing Table 2 , the dependent variable is $\log (1+$ patent intensity).

Interview and Interviewee Characteristics: For many of the regressions we run, we check that the results are robust to including interview and interviewee Characteristics, referred to as "noise" controls or variables. These include:

- Measures for the distance between ASM and MOPS reported employment for 2005 and 2010. These are calculated as the absolute values of the difference between the MOPS and ASM reported March employment for 2010 and 2005 respectively.

- Online filing indicator.

- Date of filing in calendar weeks and the date squared. This variable would capture differences in filing patterns between early and late respondents.

- Day of week.

- Tenure of the respondent, calculated as number of years since the respondent started working at the establishment (see MOPS question 31).

- Seniority of the respondent, introduced as a set of dummy variables to capture the categories in MOPS question 30 (CEO or Executive Officer, Manager of multiple establishments, Manager of one establishment, Nonmanager, Other).

\section{Appendix B: Productivity and Million Dollar Plants - congestion, spillovers and market power}

We illustrate the problem of determining the impact of MDPs on knowledge spillovers in the face of congestion costs driving up local input prices (like commercial rents). We do this in terms of capital, but the argument holds true for any input that has a local component (materials, wages, etc.)

\section{Baseline Model with congestion}

Consider our standard Cobb-Douglas production function:

$$
\log Y_{i}=\log A_{i}+\alpha \log K_{i}+\beta \log L_{i}
$$

Where $Y_{i}$ is output of plant $i, L$ is labor and $K$ is capital that are supplied at a user cost $w_{c}^{K}$ in county $c$. A natural way of thinking about this is that there is some national cost of capital (e.g. based on national interest rates) and a local component (e.g. commercial rents which depend on the constrained local supply of land). For now, assume other factor inputs are supplied solely in national markets, so there is no local component. As is typical, in our data, we do not observe the plant's quantity of capital directly. Imagine that we only have data on the capital costs (e.g. total rental charges), $w_{c}^{K} K_{i}$ and a national (or sometime industry) price deflator $\left(w^{K}\right)$. We therefore measure capital inputs as 
$\bar{K}_{l}=\frac{w_{c}^{K} K_{i}}{w^{K}} .10$ The relationship between measured and real capital in logs is:

$$
\log \bar{K}_{l}=\log K_{i}+\log \left(\frac{w_{c}^{K}}{w^{K}}\right)
$$

The measurement error will depend on the deviation of factor prices between local and national costs $\left(\frac{w_{c}^{K}}{w^{N}}\right)$.

Define the presence of a Million Dollar Plant $(M D P)$ in the county where the plant is located as $M D P_{c}=1$ and zero otherwise. We assume that there are two potential effects of an MDP. First, as discussed in the text and argued in Greenstone et al (2010) there may be an effect of MDPs on the productivity of other plants in the area (e.g. via learning better management practices). We parameterize this effect as:

$$
\log A_{i}=\log A_{0}+\pi M D P_{c}
$$

Where we expect $\pi \geq 0$. Second, the presence of an MDP could increase local factor prices by driving up the costs of commercial rents through higher demand (since the plants are very large). We parameterize this "congestion" effect as:

$$
\log \left(\frac{w_{c}^{K}}{w^{K}}\right)=\varphi M D P_{c}
$$

Where we expect $\varphi \geq 0$. Substituting equation (B3) and (B4) into the production function (B1) gives us an expression for the output relationship (using measured capital) as:

$$
\log Y_{i}=(\pi-\alpha \varphi) M D P_{c}+\log A_{0}+\beta \log L_{i}+\alpha \log \bar{K}_{l}
$$

In terms of conventionally measured TFP ("MTFP") we use industry level averages of the factor shares of total costs $\left(s_{K}, s_{L}\right)$ to measure the output elasticities of the factors $(\alpha, \beta) .11$ Under the assumptions of the model this will generate the relationship

where12

$$
\log M T F P_{i}=\left(\pi-s_{N} \varphi\right) M D P_{c}+\log A_{0}
$$

$$
\log M T F P_{i}=\log Y_{i}-s_{L} \log L_{i}-s_{K} \log \bar{K}_{l}
$$

It is clear that the coefficient on MDP consists of two offsetting effects $\left(\pi-s_{K} \varphi\right)$. The spillover effect $(\pi)$ will tend to create a positive coefficient, but the congestion effect $(\varphi)$ will create a negative coefficient, so the sign on MDP is ambiguous and reflects the net outcome of these two forces.

\section{Manufacturing vs. non-manufacturing MDPs}

Can we separately identify the productivity spillover vs. the congestion effect? Consider allowing differential effects for manufacturing vs. non-manufacturing MDPs (using superscript " $\mathrm{M}$ " and "NM" to denote manufacturing and nonmanufacturing respectively). This is plausible if we believe that some of the learning is industry-specific and/or large

10 As detailed in the Data Appendix, the construction of the capital stock is more complex than this as it uses past as well as current investment flows. The current price still enters the formula, however, so the biases will still be present. The argument that local factor price inflation induced by MDPs will cause an over-estimate of factor quantities (and therefore an underestimate of measured TFP) is quite general.

11 As noted by Hall (1988) cost shares will be accurate measures of the technology parameters even if the firm has market power as in the case of monopolistic completion (when factor shares of revenues will be less than the output elasticities due to positive price cost margins).

12 Note that although the quantity of capital is mis-measured at the plant level, the share $s_{K}$ remains correctly measured. 
international manufacturing firms are more likely to bring better technology than non-manufacturing firms. The generalized model is:

Therefore:

$$
\begin{gathered}
\log \left(\frac{w_{c}^{K}}{w^{K}}\right)=\log w^{K}+\varphi^{M} M D P_{c}^{M}+\varphi^{N M} M D P_{c}^{N M} \\
\log A_{i}=\log A_{0}+\pi^{M} M D P_{c}^{M}+\pi^{N M} M D P_{c}^{N M}
\end{gathered}
$$

$$
\operatorname{LogMTFP}_{i}=\log A_{0}+\left(\pi^{M}-s_{K} \varphi^{M}\right) M D P_{c}^{M}+\left(\pi^{N M}-s_{K} \varphi^{N M}\right) M D P_{c}^{N M}
$$

This equation gives some insight into the net effect of the different type of MDPs. Consider a simple example where all MDPs create equal congestion effects $\left(\varphi^{M}=\varphi^{N M}=\varphi\right)$, but only manufacturing plants $\left(M D P_{c}^{M}\right)$ create positive productivity spillovers $\left(\pi^{N M}=0\right)$. This gives the equation:

$$
\log M T F P_{i}=\left(\pi^{M}-s_{K} \varphi^{M}\right) M D P_{c}^{M}+s_{K} \varphi^{N M} M D P_{c}^{N M}+\log A_{0}
$$

Notice that we can now recover the spillover parameter $\pi^{M}$ from the regression coefficient on manufacturing MDPs to take account of congestion effects identified from the coefficient on non-manufacturing $\operatorname{MDPs}\left(s_{K} \varphi^{N M}\right)$.

The pattern of regression coefficients in the TFP equation is broadly similar to this simple model.

\section{Management}

The production function in equation (2) assumes that management $(M)$ is an important factor for TFP. The set-up above can be easily adapted to management by changing equation (B3) to

and

$$
\log A_{i}=\log A_{0}+\mu \log M_{i}
$$

$$
\log M_{i}=\log M_{0 i}+\pi^{M} M D P_{c}^{M}+\pi^{N M} M D P_{c}^{N M}
$$

This will generate regressions very similar to the "reduced form" TFP model above. However, it illustrates an additional test of the model. Management regressions offer us a direct way to examine whether there is a spillover from MDPs to management (and whether it differs between manufacturing and non-manufacturing MDPs). The restricted model were there are only positive productivity spillovers from manufacturing MDPs implies that we should observe $\pi^{M}>0$ and $\pi^{N M}=0$ in the regressions were management is the dependent variable. We do not have to worry about the confounding influence of congestion effects on materials input prices as we do in the TFP equation (under the plausible assumption MDPs do not drive up the factor cost of management).

\section{Mismeasurement of output prices and Product Market Competition}

In the production function literature, there has been a greater focus on mismeasurement of output prices (e.g. de Loecker, 2011) than the input price effect we discuss here. As is well known, in the absence of plant-specific output prices, MTFP will not be a quantity-based measure but rather a revenue-based measure (TFPR).13 It will contain a price-cost margin. If the entrance of an MDP creates more local output market competition this will tend to reduce price-cost margins. This will be a further effect that pushes down MTFP (Aitken and Harrison, 1999). In this case, the coefficient on MDP will then be a function of three unobserved structural parameters, causing us to underestimate the positive effects of productivity spillovers.

We can assess the importance of this competition mechanism by again disaggregating MDPs into manufacturing and non-manufacturing entrants. Since we are only looking at the impact of MDPs on manufacturing plants, we would only expect to see these negative effects at play for manufacturing MDPs as they are in similar product markets and not expect to see any negative effects from non-manufacturing MDPs competing in different markets to our plants.

13 Exceptionally, Foster, Haltiwanger, and Syverson (2008) have plant-specific output prices for a selection of homogenous good industries. 
In fact, we see almost the exact opposite in the empirical results. There is a significant negative association between the productivity of our ASM plants and non-manufacturing MDPs. As discussed above this is consistent with input congestion effects, but not product market competition. By contrast, the coefficient on manufacturing MDPs in the TFP equation is positive. To the extent that there are competition effects solely from manufacturing MDPs, this would again cause us to underestimate the importance of the positive effects of MDPs on productivity.

\section{Congestions in other factor inputs}

The congestion effects argument we make here could also be true for other inputs such as labor and materials. For intermediate inputs, local supply costs will likely rise with exactly the same mechanisms we have described. In our application, we use a value added production function, but deducting off material costs will still mean that we are creating a downward bias on TFP.

For labor, we observe employment separately from the wage bill, so it is less of an issue. In specifications where we use the wage bill to proxy for labor services and deflate by industry or national deflators, however, exactly the same issues are at play. Since we observe plant-specific wages in principle, we can test directly whether MDPs drive up the factor price for labor. The problem is that there could be other reasons for this positive correlation such as an effect on increasing unobserved skills or rent-sharing in productivity gains.

\section{Appendix Bibliography}

Aitken, Brian J., and Ann E. Harrison (1999) "Do Domestic Firms Benefit from Direct Foreign Investment? Evidence from Venezuela," American Economic Review, 89(3), 605-618.

Bloom, Nicholas, Max Floetotto, Nir Jaimovich, Itay Saporta-Eksten and Stephen Terry, (2016), "Really Uncertain Business Cycles," Stanford mimeo

De Loecker, Jan (201) "Product Differentiation, Multi-product Firms and Estimating the Impact of Trade Liberalization on Productivity", Econometrica 79(5) 1407-1451

Foster, L., Haltiwanger, J., and Syverson, C. (2008) "Reallocation, firm turnover, and efficiency: Selection on productivity or profitability?” American Economic Review, 98(1), 394-425.

Greenstone, Michael, Richard Hornbeck and Enrico Moretti, (2010), "Identifying Agglomeration Spillovers: Evidence from Winners and Losers of Large Plant Openings," Journal of Political Economy 118(3): 536-598.

Hall, Robert (1988) “The Relation between Price and Marginal cost in US Industry” Journal of Political Economy, 96(5), 921-47

Kim, Hyunseob, (2013), "Labor Market Size and Firm Capital Structure: Evidence from Large Plant Openings," Working paper. 
A1: MOPS Sample of Approximately 32,000 Manufacturing Establishments

\begin{tabular}{|c|c|c|c|c|c|}
\hline Sample & Source & Sample Criteria & $\begin{array}{l}\text { Number of } \\
\text { establishments } \\
\text { (in thousands) }\end{array}$ & $\begin{array}{l}\text { Total } \\
\text { employment } \\
\text { (in } \\
\text { thousands) } \\
\end{array}$ & $\begin{array}{l}\text { Average } \\
\text { employment }\end{array}$ \\
\hline $\begin{array}{l}\text { (1) Universe of } \\
\text { establishments }\end{array}$ & LBD & None & 7,041 & 134,637 & 19.1 \\
\hline (2) Manufacturing & LBD & NAICS 31-33 & 298 & 12,027 & 40.4 \\
\hline $\begin{array}{l}\text { (3) Annual Survey of } \\
\text { Manufactures }\end{array}$ & ASM & $\begin{array}{l}\text { NAICS } 31-33 \text {, and either } \\
\text { over } 500 \text { employees, or in } \\
\text { ASM random sample. } \\
\text { Positive employment and } \\
\text { sales, and tabbed }\end{array}$ & 51 & 7,387 & 143.5 \\
\hline $\begin{array}{l}\text { (4) MOPS } \\
\text { respondents }\end{array}$ & MOPS & $\begin{array}{l}\text { As in (3), also responded to } \\
\text { MOPS }\end{array}$ & 36 & 5,629 & 155.8 \\
\hline $\begin{array}{l}\text { (5) MOPS clean } \\
\text { (baseline sample) }\end{array}$ & MOPS & $\begin{array}{l}\text { As in (4) with } 11+\text { non- } \\
\text { missing responses, match } \\
\text { to ASM, tabbed in ASM } \\
\text { and have positive value } \\
\text { added, employment and } \\
\text { imputed capital in ASM } \\
2010\end{array}$ & 32 & 5,308 & 167 \\
\hline
\end{tabular}

Note: The LBD numbers are from 2009. ASM and MOPS numbers are for 2010. 
Table A2: Descriptive Statistics

\begin{tabular}{lccccccc} 
A. Management Descriptives & Mean & S.D. & $\mathbf{p ( 1 0 )}$ & $\mathbf{p}(\mathbf{2 5})$ & $\mathbf{p ( 5 0 )}$ & $\mathbf{p ( 7 5 )}$ & $\mathbf{p ( 9 0 )}$ \\
\hline Management score & 0.640 & 0.152 & 0.427 & 0.553 & 0.667 & 0.753 & 0.812 \\
Data driven performance monitoring & 0.665 & 0.180 & 0.417 & 0.556 & 0.694 & 0.806 & 0.868 \\
Incentives and targets & 0.623 & 0.176 & 0.381 & 0.526 & 0.650 & 0.750 & 0.825 \\
B. Establishment Characteristics & & & & & & & \\
\hline Size & 167.0 & 385.1 & 15.0 & 33.6 & 80.0 & 174.9 & 359.0 \\
Parent firm size & 3332.6 & 8739.8 & 24.0 & 60.0 & 258.3 & 1938.7 & 8327.6 \\
Establishment Age & 22.0 & 12.1 & 4.0 & 11.0 & 24.0 & 35.0 & 35.0 \\
Parent firm age & 28.4 & 10.4 & 9.0 & 24.0 & 35.0 & 35.0 & 35.0 \\
\% of managers with degree & $43.6 \%$ & $31.1 \%$ & $10.0 \%$ & $10.0 \%$ & $43.6 \%$ & $70.0 \%$ & $90.0 \%$ \\
\% of non-managers with degree & $9.4 \%$ & $12.0 \%$ & $0.0 \%$ & $5.0 \%$ & $5.0 \%$ & $15.0 \%$ & $40.0 \%$ \\
\% of union members & $12.6 \%$ & $27.6 \%$ & $0.0 \%$ & $0.0 \%$ & $0.0 \%$ & $0.0 \%$ & $70.0 \%$ \\
Exporter & $42.2 \%$ & $49.4 \%$ & 0 & 0 & 0 & 1 & 1 \\
Multi-unit Parent & $69 \%$ & $46.2 \%$ & 0 & 0 & 1 & 1 & 1 \\
\hline \hline
\end{tabular}

Note: The management score is the unweighted average of the score for each of the 16 questions, where each question is first normalized to be on a 0-1 scale. The sample in all columns is all MOPS observations with at least 11 non-missing responses to management questions and a successful match to ASM, which were also included in ASM tabulations, have positive value added, positive employment and positive imputed capital in the ASM. For the few cases where establishment characteristics had missing values (for the degree and union questions), we replaced these with the means in the sample, so to keep a constant sample size. P(n) is the value at the $\mathrm{n}$-th percentile, e.g. p(50) is the median value (fuzzed).

Table A3: Linear regressions for sample selection

\begin{tabular}{lccccc}
\hline \hline & & & & & \\
& $\begin{array}{c}\text { Mailed MOPS vs } \\
\text { ASM }\end{array}$ & $\begin{array}{c}\text { MOPS Respondents vs. } \\
\text { Mailed MOPS }\end{array}$ & $\begin{array}{c}\text { Clean sample vs. } \\
\text { MOPS } \\
\text { respondents }\end{array}$ & $\begin{array}{c}\text { Clean } \\
\text { sample vs. } \\
\text { ASM }\end{array}$ & $\begin{array}{c}\text { Clean } \\
\text { sample vs. } \\
\text { ASM }\end{array}$ \\
\hline Log(employment) & $0.059^{* * *}$ & $0.031^{* * *}$ & $0.057^{* * *}$ & $0.096^{* * *}$ & $0.094^{* * *}$ \\
& $(0.002)$ & $(0.002)$ & $(0.002)$ & $(0.002)$ & $(0.002)$ \\
Log(sales/employment) & & & & $0.038^{* * *}$ \\
& & & 1.1 & 34.665 & 33.443 \\
F-stat (region) & 5.591 & 45.381 & $(0.348)$ & $(0)$ & $(0)$ \\
(p-value) & $(0.001)$ & $(0)$ & 8.399 & 15.267 & 11.948 \\
F-stat (industry) & 10.213 & 7.871 & $(0)$ & $(0)$ & $(0)$ \\
(p-value) & $(0)$ & $(0)$ & 36,140 & 51,461 & 51,461 \\
\hline Observations & 51,461 & 47,503 & 20,694 & 28,905 & 28,905 \\
Number of firms & 28,905 & 26,345 & & & \\
\hline \hline
\end{tabular}

Note: The table reports the results from linear probability regressions. In column 1 the sample is 2010 ASM observations with positive employment and sales, which were tabbed, and the dependent variable is an indicator that equals 1 if MOPS was sent to the establishment. In column 2 the sample is the subsample of the one in column 1, also conditioning on MOPS mailed, and the dependent variable is an indicator that equals 1 if MOPS survey was filled. In column 3 the sample is the subsample of the one in column 2, also conditioning on MOPS respondent, and the dependent variable is an indicator that equals 1 if the observation is in our baseline "clean" sample. In columns 4 and 5 the sample is as in column 1, and the dependent variable is an indicator that equals 1 if the observation is in our baseline "clean" sample. Standard errors are clustered at the firm level. 


\section{Table A4: Measurement Error is Independent of Observables}

Dependent Variable

Absolute Value of Diff in Management Score

Between Double Surveyed Establishments

$\log ($ number plants in the firm - CM)

(1)

(2)

(3)

(4)

(5)

(6)

$\log$ (number plants in the firm - LBD)

$(0.0070)$

0.0018

(0.0048)

$\log ($ employees in the plant)

$(0.0143)$

$\log ($ employees in the firm - CM)

Log(employees in the firm - LBD)

(0.0047)

Log(firm age)

Observations 500

500

500

500

500

500

Note: The management score is the unweighted average of the score for each of the 16 questions, where each question is first normalized to be on a 0 - 1 scale. The sample is approximate 500 plants from the baseline sample that filled-out two surveys by different responders for MOPS 2010 . The exact number of plants is suppressed to prevent disclosure of confidential information.

Table A5: Management and Performance Relation over Industries and Counties

\begin{tabular}{|c|c|c|c|c|}
\hline & \multicolumn{2}{|c|}{ Between Industry } & \multicolumn{2}{|c|}{ Between Counties } \\
\hline & $\begin{array}{c}\text { Emp. Growth } \\
2010-2013\end{array}$ & $\begin{array}{c}\text { Exit } \\
2010 \text { to } 2013\end{array}$ & $\begin{array}{c}\text { Emp. Growth } \\
2010-2013\end{array}$ & $\begin{array}{c}\text { Exit } \\
2010 \text { to } 2013\end{array}$ \\
\hline Management & $\begin{array}{c}0.089 * * * \\
(0.022)\end{array}$ & $\begin{array}{c}-0.023 * * \\
(0.010)\end{array}$ & $\begin{array}{c}0.111 * * * \\
(0.022)\end{array}$ & $\begin{array}{c}-0.033 * * * \\
(0.009)\end{array}$ \\
\hline Observations & 471 & 471 & 2,450 & 2,450 \\
\hline
\end{tabular}

Notes: $* * *$ significant at $1 \%$ level, $* * 5 \%$ level, $* 10 \%$ level. OLS coefficients with standard errors in parentheses. The management score is the unweighted average of the score for each of the 16 questions, where each question is first normalized to be on a $0-1$ scale. The sample in all columns is all MOPS observations with at least 11 non-missing responses to management questions and a successful match to ASM, which were also included in ASM tabulations, have positive value added, positive employment and positive imputed capital in the ASM. In columns (1) and (3) the dependent variable is employment growth between 2010 and 2013 . Growth is calculated as $0.5 *\left(\mathrm{e}_{2013}-\mathrm{e}_{2010}\right) /\left(\mathrm{e}_{2013}+\mathrm{e}_{2010}\right)$. In columns (2) to (4) the dependent variable is a dummy that takes the value of 1 for exit between 2010 and 2013. In columns (1) and (3) the data was first collapsed to the 471 NAICS industry codes, and for columns (2) and (4) it was collapsed to the county level. 
Table A6: MDP Balancing Tests

\begin{tabular}{|c|c|c|c|c|}
\hline & $\begin{array}{c}\text { All } \\
\text { industries } \\
\text { Pooled } \\
(1) \\
\end{array}$ & $\begin{array}{c}\text { Million Dollar } \\
\text { Plant Opens } \\
\times(\text { Manufacturing }) \\
(2) \\
\end{array}$ & $\begin{array}{l}\text { Million Dollar } \\
\text { Plant Opens } \\
\times \text { (Non-Manuf.) } \\
(3)\end{array}$ & Observations \\
\hline \multicolumn{5}{|l|}{ Panel A: 2005 Levels of: } \\
\hline Management score & $\begin{array}{l}-0.016 \\
(0.018)\end{array}$ & $\begin{array}{l}-0.028 \\
(0.026)\end{array}$ & $\begin{array}{c}0.015 \\
(0.024)\end{array}$ & 1,152 \\
\hline $\log (\mathrm{TFP})$ & $\begin{array}{l}-0.005 \\
(0.053)\end{array}$ & $\begin{array}{l}-0.042 \\
(0.028)\end{array}$ & $\begin{array}{c}0.094 \\
(0.112)\end{array}$ & 1,152 \\
\hline Log(employment) & $\begin{array}{c}-0.233^{* *} \\
(0.110)\end{array}$ & $\begin{array}{c}-0.341^{* *} \\
(0.173)\end{array}$ & $\begin{array}{c}0.052 \\
(0.140)\end{array}$ & 1,152 \\
\hline Establishment age & $\begin{array}{c}0.297 \\
(1.077)\end{array}$ & $\begin{array}{c}0.490 \\
(1.324)\end{array}$ & $\begin{array}{l}-0.210 \\
(2.088)\end{array}$ & 1,152 \\
\hline Share of employees with a degree & $\begin{array}{c}0.076 \\
(0.960)\end{array}$ & $\begin{array}{c}0.302 \\
(0.618)\end{array}$ & $\begin{array}{l}-0.517 \\
(3.167)\end{array}$ & 1,152 \\
\hline share of employees in a union & $\begin{array}{c}0.064 \\
(0.041) \\
\end{array}$ & $\begin{array}{c}0.099 * * * \\
(0.033) \\
\end{array}$ & $\begin{array}{l}-0.029 \\
(0.040) \\
\end{array}$ & 1,152 \\
\hline \multicolumn{5}{|c|}{ Panel B: 2000 to 2005 Change in (establishment level): } \\
\hline $\log (\mathrm{TFP})$ & $\begin{array}{l}-0.093 \\
(0.059)\end{array}$ & $\begin{array}{l}-0.103 \\
(0.067)\end{array}$ & $\begin{array}{l}-0.065 \\
(0.094)\end{array}$ & $\sim 1,600$ \\
\hline Log(employment) & $\begin{array}{c}0.047 \\
(0.034)\end{array}$ & $\begin{array}{c}0.026 \\
(0.043)\end{array}$ & $\begin{array}{c}0.102 \\
(0.086)\end{array}$ & $\sim 1,600$ \\
\hline \multicolumn{5}{|l|}{ Panel C: 2000 to 2005 (county level): } \\
\hline Change in $\log (\#$ establishments $)$ & $\begin{array}{l}-0.025 \\
(0.034)\end{array}$ & $\begin{array}{l}-0.028 \\
(0.052)\end{array}$ & $\begin{array}{l}-0.0210 \\
(0.045)\end{array}$ & 45 \\
\hline Change in $\log$ (\#manufacturing plants) & $\begin{array}{l}-0.056 \\
(0.050)\end{array}$ & $\begin{array}{l}-0.098 \\
(0.071)\end{array}$ & $\begin{array}{l}-0.005 \\
(0.065)\end{array}$ & 45 \\
\hline Exit rate & $\begin{array}{l}-0.004 \\
(0.014)\end{array}$ & $\begin{array}{l}-0.008 \\
(0.016)\end{array}$ & $\begin{array}{c}0.001 \\
(0.024)\end{array}$ & 45 \\
\hline Exit rate in manufacturing & $\begin{array}{c}0.001 \\
(0.022)\end{array}$ & $\begin{array}{c}0.015 \\
(0.031)\end{array}$ & $\begin{array}{l}-0.018 \\
(0.026)\end{array}$ & 45 \\
\hline Birth rate & $\begin{array}{l}-0.033 \\
(0.046)\end{array}$ & $\begin{array}{l}-0.041 \\
(0.062)\end{array}$ & $\begin{array}{l}-0.022 \\
(0.071)\end{array}$ & 45 \\
\hline Birth rate in manufacturing & $\begin{array}{l}-0.078 \\
(0.064)\end{array}$ & $\begin{array}{l}-0.118 \\
(0.084)\end{array}$ & $\begin{array}{l}-0.028 \\
(0.099)\end{array}$ & 45 \\
\hline
\end{tabular}

Notes: The sample in panel A is identical to the MDP sample in Table 7, and the variables are the same ones used in the regressions in Table 7. In panel B the sample includes all ASM establishments with valid TFP for 2000 and 2005 in counties which were included in the MDP analysis in Table 7. In panel $\mathrm{C}$ we report aggregate statistics from the Longitudinal Business Database (LBD) for the sample of counties which were part of the MDP analysis. Column 1 reports results from a regression of each variable on the MDP dummy, while columns (2) and (3) report the results from a regression where MDP dummies are interacted with a dummy indicating whether the MDP was manufacturing or not. 


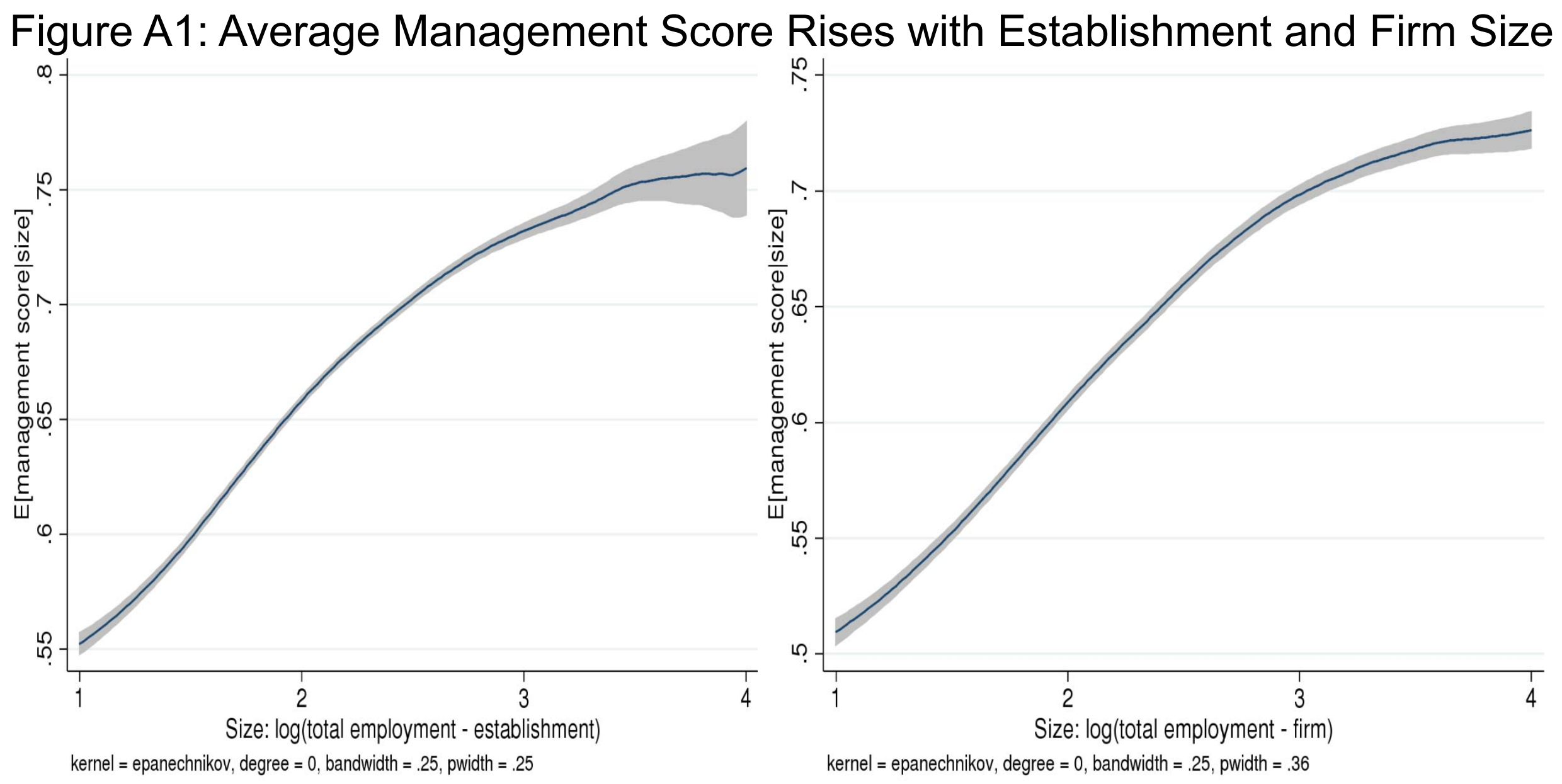

Note: The management score is the unweighted average of the score for each of the 16 questions, where each question is first normalized to be on a 0-1 scale. The sample is all MOPS observations with at least 11 non-missing responses to management questions and a successful match to ASM, which were also included in ASM tabulations, and have positive value added, positive employment and positive imputed capital in the ASM. The figure further restricts to establishments with 10 employees or more, and winsorizes establishment size at 10,000 employees. The figure was generated using a local mean smoother with Epanechnikov kernel and 0.25 bandwidth. The $X$ axis is base 10 logarithm. 
Figure A2: The firm-level share of the variation in management scores (after removing measurement error) with a white-noise placebo

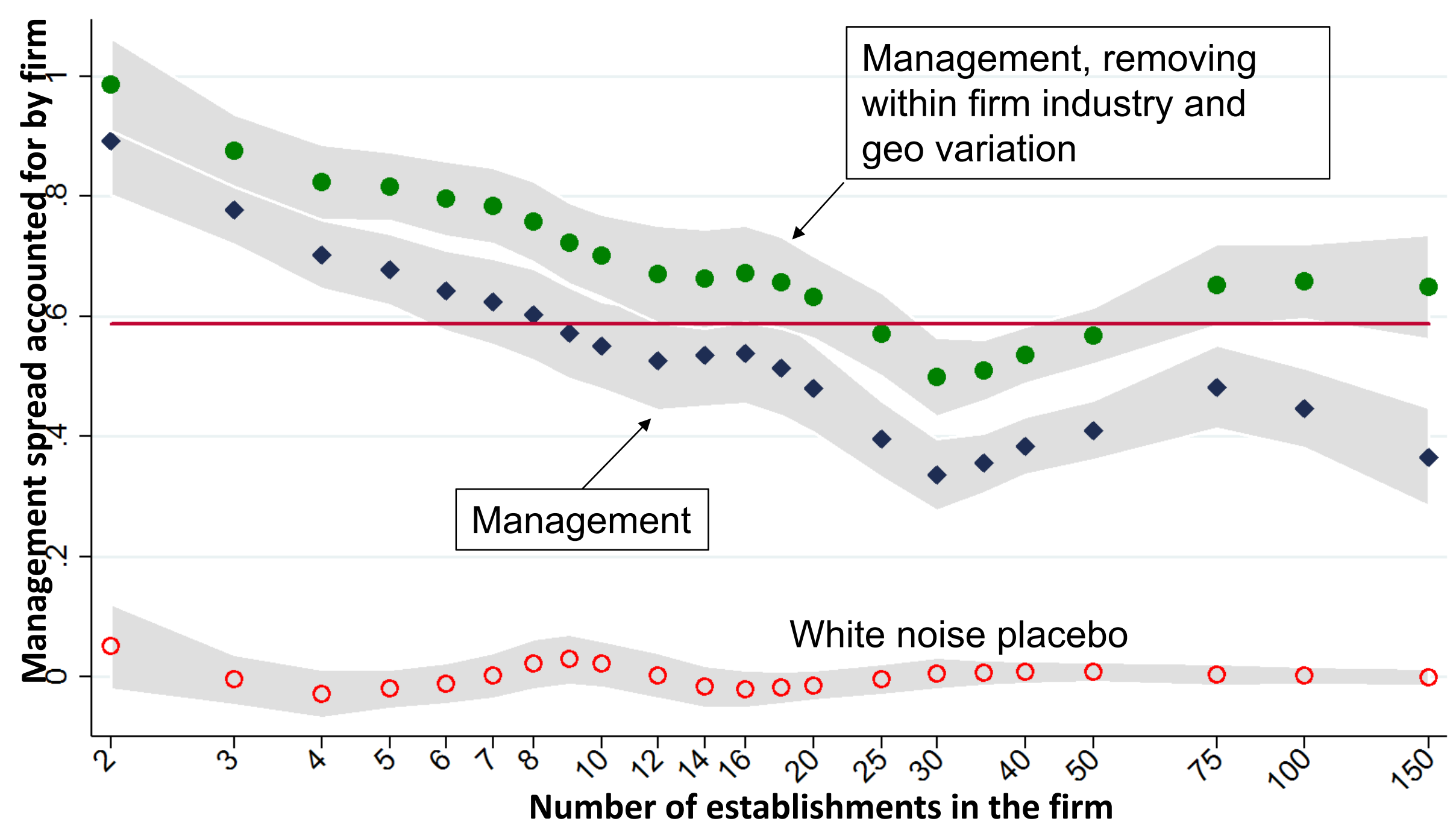

Note: Blue dots show the share of management score variation accounted for by the firm with different numbers of establishments after removing the $45.4 \%$ accounted for by measurement error. Red dots are the share of white noise accounted for by the firm in the same sample, as a placebo test for the validity of the approach. Bootstrap sampled $95 \%$ confidence interview shown in grey shading. Sample of the 16,500 establishments in the 3,100 firms with 2+ establishments in the MOPS 2010 survey. 